NBER WORKING PAPER SERIES

\title{
BANK REGULATION AND SUPERVISION: WHAT WORKS BEST?
}

\author{
James R. Barth \\ Gerard Caprio, Jr. \\ Ross Levine \\ Working Paper 9323 \\ http://www.nber.org/papers/w9323 \\ NATIONAL BUREAU OF ECONOMIC RESEARCH \\ 1050 Massachusetts Avenue \\ Cambridge, MA 02138 \\ November 2002
}

This research could not have been completed without the help of Iffath Sharif and Cindy Lee, as well as financial support from the World Bank. Xin Chen provided extraordinary research assistance. We received helpful comments from Asli Demirgüç-Kunt, Simeon Djankov, Patrick Honohan, George Kaufman, Soledad Martinez, Charles Calomiris, Rick Mishkin, Andrei Shleifer, Gerardo Zuniga-Villasenor, Ernst-Ludwig von Thadden, Mitch Petersen, an anonymous referee, and seminar participants at the Banco Central de Chile, the BIS, The World Bank's Annual Bank Conference on Development Economics, Brookings-Wharton Financial Services Conference, University of Minnesota, The Reserve Bank of Australia, Harvard University, Stanford University, and University of Michigan. The findings do not necessarily represent the opinions of The World Bank, its management, the Executive Directors, or the countries they represent. The views expressed herein are those of the authors and not necessarily those of the National Bureau of Economic Research.

(C) 2002 by James R. Barth, Gerard Caprio, Jr. and Ross Levine. All rights reserved. Short sections of text, not to exceed two paragraphs, may be quoted without explicit permission provided that full credit, including (C) notice, is given to the source. 
Bank Regulation and Supervision: What Works Best?

James R. Barth, Gerard Caprio, Jr. and Ross Levine

NBER Working Paper No. 9323

November 2002

JEL No. G38, G21, L51

\begin{abstract}
This paper uses our new database on bank regulation and supervision in 107 countries to assess the relationship between specific regulatory and supervisory practices and banking-sector development, efficiency, and fragility. The paper examines: (i) regulatory restrictions on bank activities and the mixing of banking and commerce; (ii) regulations on domestic and foreign bank entry; (iii) regulations on capital adequacy; (iv) deposit insurance system design features; (v) supervisory power, independence, and resources, (vi) loan classification stringency, provisioning standards, and diversification guidelines; (vii) regulations fostering information disclosure and privatesector monitoring of banks; and (viii) government ownership. The results, albeit tentative, raise a cautionary flag regarding government policies that rely excessively on direct government supervision and regulation of bank activities. The findings instead suggest that policies that rely on guidelines that (1) force accurate information disclosure, (2) empower private-sector corporate control of banks, and (3) foster incentives for private agents to exert corporate control work best to promote bank development, performance and stability.
\end{abstract}

James R. Barth

Auburn Unviersity

and Milken Institute

jbarth@business.auburn.edu
Gerard Caprio, Jr.

World Bank

gcaprio@worldbank.org
Ross Levine

Carlson School of Management

University of Minnesota

321 19th Avenue South

Minneapolis, MN 55455

and NBER

rlevine@csom.umn.edu 


\section{Introduction}

The staggering scope of recent banking crises coupled with strong evidence on the beneficial effects of well-functioning banking systems for economic growth underscore current efforts to reform bank regulation and supervision. ${ }^{1}$ In January 2001, the Basel Committee on Banking Supervision issued a proposal for a Basel II Capital Accord that, once finalized, will replace the 1988 Basel I Capital Accord. The proposal is based on three pillars. The first deals with improved minimum bank capital requirements, the second focuses on better supervisory practices, and the third envisions greater market discipline through increased information disclosed by banks. Once the Basel Committee finalizes its list of "best practices" for the regulation and supervision of banks, countries around the world will be urged to adopt them. The belief is that the banking sectors in countries adopting these practices will function better, thereby promoting growth and stability.

Unfortunately, however, there is no evidence: that any universal set of best practices is appropriate for promoting well-functioning banks; that successful practices in the United States, for example, will succeed in countries with different institutional settings; or that detailed regulations and supervisory practices should be combined to produce an extensive checklist of best practices in which more checks are better than fewer. There is no broad cross-country evidence on which of the many different regulations and supervisory practices employed around the world work best, if at all, to promote bank development and stability.

This paper attempts to help close this gap by examining the relationship between bank regulation and supervision and bank development, performance and stability using our newly assembled database. We conducted a survey of national regulatory agencies and obtained information on numerous bank regulations and supervisory practices in 107 countries. The data, primarily from 1999, are used to assess which regulations and supervisory practices are associated with greater bank development, better performance, and increased stability as well as those that are not. We specifically examine regulations on bank activities and the mixing of banking and commerce; regulations on domestic and foreign bank entry; regulations on capital adequacy; deposit insurance; supervisory power, independence, and resources; loan classification stringency, provisioning standards,

\footnotetext{
${ }^{1}$ On crises, see Caprio and Klingebiel (1999) and Boyd, Kwak and Smith (2000). On growth, see Levine (1997).
} 
diversification guidelines; regulations fostering information disclosure and private-sector monitoring of banks; and government ownership of banks. Thus, this paper provides empirical evidence on each of the three pillars associated with the Basel II Capital Accord.

Economic theory provides conflicting predictions about the effects of each of these bank regulations and supervisory practices on bank development, performance, and stability. Some argue, for example, in favor of restricting banks from participating in securities, insurance, and real estate activities or from owning nonfinancial firms. They stress that (i) neither private nor official entities can effectively monitor such complex banks due to informational asymmetries and (ii) both the market and political power enjoyed by such banks can impede competition and adversely influence policies.

Others argue the opposite, stressing that (i) informational asymmetries are not that great, (ii) potential adverse spillovers to the entire economy are not sufficient to warrant such restrictions, and (iii) fewer restrictions allow banks to exploit economies of scale and scope and thereby provide services more efficiently. An examination of countries with different regulations for bank activities can help resolve this debate. More generally, we discuss the theoretical predictions surrounding each of the regulations and supervisory practices noted above in subsequent sections and then empirically examine its relationship to bank development, performance and stability.

Theory also provides more subtle predictions about the precise conditions under which regulations and supervisory practices enhance bank development, performance and stability. Some models, for instance, predict that the correct answer to the question as to whether countries should restrict bank activities is "it depends on other policies and institutions." Boyd, Chang, and Smith (1998) argue that in a country with generous deposit insurance that intensifies moral hazard problems, broad banking powers provide excessive opportunities for risk-taking. Thus, they conclude that restrictions on bank activities enhance social welfare in countries with generous deposit insurance. Similarly, while capital requirements are the mainstay of current approaches to bank regulation and supervision, theory predicts that such requirements are particularly beneficial when (i) generous deposit insurance distorts incentives, (ii) official supervision is weak, and (iii) complex banks are difficult to monitor. For these reasons, analyses of individual regulations and supervisory practices should incorporate interaction terms to assess the efficacy of each one in the presence of others. We describe and empirically examine many of these more subtle predictions.

We examine an extensive array of regulations and supervisory practices for a broad cross- 
section of countries at all levels of development and in all parts of the world. The issues are so extensive that one may question our expansive approach, preferring more narrowly focused examinations of individual issues. While recognizing the advantages of tightly focused studies, we follow the growing literature stressing that the salient issues in bank regulation and supervision are inextricably interrelated. Thus, there are advantages to examining an array of supervisory and regulatory policies simultaneously to identify those that enjoy a strong, independent relationship with financial development and stability. It is perilous, for example, to examine the efficacy of supervisory practices without accounting for private sector monitoring. It is risky to examine restrictions on bank securities activities without considering the power of supervisory authorities. As a final example, there are important shortcomings with examining regulations and supervisory practices without accounting for the degree of government ownership of banks. Furthermore, given that this paper introduces a new database on bank regulation and supervision, it is natural to provide a first assessment of which regulations and supervisory practices are associated with successful outcomes across countries. Thus, we simultaneously examine the relationships between numerous regulations and supervisory practices and selected banking-sector outcomes using a broad cross-section of countries.

There are two particularly important methodological limitations to our study. One limitation is that we conduct pure cross-country regressions because information on regulations and supervisory practices is available only for one point in time. A problem with this approach is that it is difficult to control fully for potential simultaneity bias: banking-sector outcomes may influence regulations and supervisory practices. We do use instrumental variables to help control for simultaneity bias and these procedures do pass basic specification tests. Nonetheless, data limitations do not allow us to use timeseries or panel procedures to examine the same relationships using complementary methods. We were able to collect historical data for a few variables, however, and found very little change over time. Moreover, controlling for any changes does not alter our findings. The other limitation is that only aggregate measures of bank performance are used. Nevertheless, we are in the process of complementing and refining our analyses by employing firm-level, industry-level, and bank-level datasets and we make our regulation and supervisory available so that others can extend this paper's work. Such complementary studies will provide additional insights into the influence of bank regulatory and supervisory practices on various banking-sector outcomes. Until then, our cross-country study provides a first, tentative assessment of the relationships between bank development, performance and stability and the regulation and supervision of banks around the world. 
Before continuing, we note that this paper is naturally related to a long, vast literature on the overall role of the government in regulating economic activity (Pigou, 1938; Stigler, 1971). Each of the specific regulatory/supervisory issues noted above could be framed in terms of arguments for greater government intervention -- and the form that those interventions should take -- and arguments against direct government interventions. Many arguments in favor of government intervention are Pigouvian: the existence of monopoly power, externalities, and informational asymmetries create a potentially constructive role for government interventions to offset these market failures and enhance social welfare. The Pigouvian view takes as given both that there are market failures and that the government can and will act to ameliorate those failures. Others disagree. Some argue that market failures are not very large. Others argue that governments act in their own interests and frequently do not ameliorate market failures (Shleifer and Vishny, 1998). According to this view, regulations that empower the private-sector to monitor banks will be more effective than direct government interventions at enhancing bank performance and stability. Our analyses provide evidence regarding the efficacy of direct government interventions in the banking sector.

The paper is organized as follows. Section II discusses the theoretical and policy debates surrounding each of the issues noted earlier. Section III discusses our dataset and some basic correlations. Section IV presents regression results, while Section V contains conclusions

\section{Theoretical and Policy Debates}

This section discusses seven policy issues. For each issue, we: (1) stress the conflicting theoretical predictions and policy debates, (2) emphasize that specific regulations and supervisory practices are so inextricably interrelated it is important to examine them simultaneously.

\section{II.A. Regulations on bank activities and banking-commerce links}

There are five main theoretical reasons for restricting bank activities and banking-commerce links. First, conflicts of interest may arise when banks engage in such diverse activities as securities underwriting, insurance underwriting, and real estate investment. Such banks, for example, may attempt to "dump" securities on ill-informed investors to assist firms with outstanding loans [John, John, and Saunders (1994) and Saunders (1985)]. Second, to the extent that moral hazard encourages riskier behavior, banks will have more opportunities to increase risk if allowed to engage in a broader 
range of activities [Boyd, Chang, and Smith (1998)]. Third, complex banks are difficult to monitor. Fourth, such banks may become so politically and economically powerful that they become "too big to discipline." Finally, large financial conglomerates may reduce competition and efficiency. According to these arguments, governments can improve banking by restricting bank activities.

There are alternative theoretical reasons for allowing banks to engage in a broad range of activities, however. First, fewer regulatory restrictions permit the exploitation of economies of scale and scope [Claessens and Klingebiel (2000)]. Second, fewer regulatory restrictions may increase the franchise value of banks and thereby augment incentives for more prudent behavior. Lastly, broader activities may enable banks to diversify income streams and thereby create more stable banks.

In an earlier study, we found that greater restrictions are associated: (1) a higher probability of suffering a major banking crisis, and (2) lower banking-sector efficiency [Barth, Caprio, and Levine, 2001a]. We found no countervailing positive effects. Restricting bank activities were not closely associated with less concentration, more competition, or greater securities-market development.

This paper expands and improves on our earlier research. First, we now have regulation and supervision data for substantially (50\%) more countries. Second, we assess whether the positive association that was found between restrictions and banking crises simply reflected the effects of significant omitted variables. Countries with more effective supervision, for example, may impose fewer restrictions. If so, the positive relationship between regulatory restrictions and crises we initially found might simply reflect the fact that countries with weaker supervision compensate by imposing more restrictions on bank activities. Also, we assess whether our initial finding of a positive association between restrictions and crises reflects another omitted variable: the deposit insurance scheme. Countries with deposit insurance schemes that do not severely distort incentives toward greater risk-taking may impose fewer restrictions on bank activities. If so, the positive relationship between restrictions and crises may simply reflect the fact that countries imposing more restrictions do so to compensate for generous deposit-insurance schemes. 


\section{II.B. Regulations on domestic and foreign bank entry}

Economic theory provides conflicting views on the need for and the effect of regulations on entry into banking. Some argue that effective screening of bank entry can promote stability. Others stress that banks with monopolistic power possess greater franchise value, which enhances prudent risk-taking behavior [Keeley (1990)]. Others, of course, disagree, stressing the beneficial effects of competition and the harmful effects of restricting entry [Shleifer and Vishny, 1998].

This paper assesses whether greater restrictions on the entry of foreign and domestic banks are associated with less bank development, worse performance and more fragility. This helps fill a lacuna because existing cross-country studies do not use direct measures of entry policies. ${ }^{2}$ Also, we assess whether the relationship between bank development and competition policies depends on regulatory restrictions on bank activities, the power and independence of bank supervisory authorities, the deposit insurance scheme, capital adequacy requirements, the degree of equity market development, and the extent of government ownership of banks. Our dataset enables us to explore whether the relationships between competition and bank development, performance, and stability depend on these other factors.

\section{II.C. Regulations on capital adequacy}

Traditional approaches to bank regulation emphasize the positive features of capital adequacy requirements [Dewatripont and Tirole (1994)]. Capital serves as a buffer against losses and hence failure. Furthermore, with limited liability, the proclivity for banks to engage in higher risk activities is curtailed with greater amounts of capital at risk. Capital adequacy requirements, especially with deposit insurance, play a crucial role in aligning the incentives of bank owners with depositors and other creditors [Berger, Herring and Szego (1995) and Keeley and Furlong (1990)].

As reviewed in Santos (2001), however, theory provides conflicting predictions as to whether the imposition of capital requirements reduces risk-taking incentives. For instance, Koehn and Santomero (1980), Kim and Santomero (1988), and Blum (1999) argue that capital requirements may increase risk-taking behavior. Given (i) conflicting theoretical predictions, (ii) Alan Greenspan's (1998) view that existing capital requirements are arbitrary and inadequate, and (iii) the controversy over the attempt to set new risk-based capital requirements in the Basel II Capital Accord, it seems

\footnotetext{
${ }^{2}$ It is crucial to focus on entry policies since one may simultaneously observe increasing concentration and
} 
especially timely and important to examine the association between capital requirements and bankingsector outcomes across countries.

This paper examines the relationship between capital regulations and bank development and stability. Moreover, we do not consider the relationships between capital regulations and bankingsector outcomes in isolation. We consider counterfactuals in which these relationships may depend on other regulations and supervisory practices. The degree to which capital requirements are associated with bank development, performance and fragility, for example, may depend upon the specific features of any deposit insurance scheme [e.g., Mullins and Pyle, 1994]. The marginal relationship between capital regulations and bank behavior may also depend importantly on the powers granted supervisors.

\section{II.D. Deposit insurance design}

Countries adopt deposit insurance schemes to prevent widespread bank runs. ${ }^{3}$ If depositors attempt to withdraw their funds all at once, illiquid but solvent banks may be forced into insolvency. To protect payment and credit systems from contagious bank runs, many favor deposit insurance plus powerful official oversight of banks to augment private-sector monitoring of banks.

Deposit insurance schemes come at a cost, however. They may encourage excessive risk-taking behavior, which some believe offsets any stabilization benefits. Yet, many contend that regulation and supervision can control the moral-hazard problem by designing an insurance scheme that encompasses appropriate coverage limits, scope of coverage, coinsurance, funding, premia structure, management and membership requirements. ${ }^{4}$

We examine the relationship between deposit insurance and bank development and efficiency and also assess whether this relationship depends on the extent of capital regulations, official supervisory powers, regulatory restrictions on bank activities, and on the extent to which private-sector monitoring of banks is promoted. Recently, Demirgüç-Kunt and Detragiache (2002) made a

increasing competition [e.g., Boot and Thakor, 1997, 2000; Berger, Demsetz, and Strahan, 1999].

${ }^{3}$ After the adoption of a national deposit insurance system in the United States in 1934, other countries adopted explicit systems slowly for the first 30 years, with only 6 being established. Then adoptions accelerated: 22 formal systems existed by the $50^{\text {th }}$ anniversary of the U.S. system, about 70 systems were in place by the close of 2000 , and many other countries are planning on adopting explicit deposit insurance schemes.

${ }^{4}$ As Dewatripont and Tirole (1994) show for risk-based capital requirements, it is possible theoretically that riskbased deposit insurance will induce greater risk-taking. Once the (capital requirement or) risk-based deposit insurance premia is fixed, bankers may respond by taking greater risk in an attempt to earn their 'required' return. 
substantial contribution to the banking literature by measuring the effects of the design of deposit insurance on bank fragility. ${ }^{5}$ Due to data limitations, however, their analysis could not control for other aspects of regulation and supervision. With our new database, we control for a wide variety of regulations and supervisory practices in assessing the relationship between deposit insurance and bank development, performance and fragility.

\section{II.E. Supervision}

Some theoretical models stress the advantages of granting broad powers to supervisors. The reasons are as follows. First, banks are costly and difficult to monitor. This leads to too little monitoring of banks, which implies sub-optimal performance and stability. Official supervision can ameliorate this market failure. Second, because of informational asymmetries, banks are prone to contagious and socially costly bank runs. Supervision in such a situation serves a socially efficient role. Third, many countries choose to adopt deposit insurance schemes. This situation: (1) creates incentives for excessive risk-taking by banks, and (2) reduces the incentives for depositors to monitor banks. Strong, official supervision under such circumstances can help prevent banks from engaging in excessive risk-taking behavior and thus improve bank development, performance and stability.

Alternatively, powerful supervisors may exert a negative influence by using their powers to benefit favored constituents, attract campaign donations, and extract bribes [Shleifer and Vishny, 1998; Djankov, et. al., 2002; and Quintyn and Taylor, 2002]. If so, there will be less interest in overcoming market failures and more interest in seeking personal gain. Powerful supervision under these circumstances will be positively related to corruption and will not improve bank development, performance and stability.

Countries in practice may assign very different priorities to bank supervision. We can use our database to assess the relationships of official supervisory resources, powers, and independence to banking-sector outcomes with: (a) the extent of private-sector monitoring, (b) restrictions on bank activities, and (c) the degree of moral hazard created by deposit insurance schemes. We can also assess the relationships between loan classification and provisioning policies and bank development, performance, and stability. Furthermore, we can examine restrictions on international lending that may

\footnotetext{
${ }^{5}$ Briefly, they find that high coverage limits and scope, having a funded scheme, and exclusively public-sector participation and management all positively contribute to the likelihood of a crisis.
} 
hinder diversification.

Although these supervisory practices form the core of many recommendations to improve supervision, this paper provides the first cross-country evidence on which supervisory practices are positively associated with greater bank development, performance and stability.

\section{II.F. Regulations on private-sector monitoring of banks}

Supervisory agencies may encourage private monitoring. Our data indicate that some supervisory agencies require banks to obtain certified audits and/or ratings from international-rating agencies. Some supervisory agencies require banks to produce accurate, comprehensive and consolidated information on the full range of their activities and risk-management procedures. Some countries even make bank directors legally liable if information is erroneous or misleading. Also, some countries credibly impose a "no deposit insurance" policy to stimulate private monitoring.

There are disagreements about the role of the private sector in monitoring banks. Some advocate more reliance on private-sector monitoring, expressing misgivings with official supervision of banks. Recently, for instance, the Shleifer and Vishny (1998) view of government regulations specifically holds that banks will pressure politicians who, in turn, can unduly influence supervisory oversight. Furthermore, in some countries, supervisors are not well compensated and hence quickly move into banking, resulting in a situation in which they may face mixed incentives when it comes to strictly adhering to the rules. Since supervisors do not have their own wealth invested in banks, they also have different incentives than private creditors insofar as monitoring and disciplining banks. There are countervailing arguments, however. Countries with poorly-developed capital markets, accounting standards, and legal systems may not be able to rely effectively on private monitoring. Furthermore, the complexity and opacity of banks may make private sector monitoring difficult even in the most developed economies. From this perspective, therefore, excessively heavy reliance on private monitoring may lead to the exploitation of depositors and poor bank performance.

This paper examines the relationships between regulations and supervisory practices designed to promote private-sector monitoring and bank development, performance, and stability, while controlling for other regulations and supervisory practices. It also assesses the private-monitoring relationships in countries with particular types of policies and institutions as will be discussed below. 


\section{II.G. Government ownership of banks}

Economists hold different views about the impact of government ownership of banks. One view holds that governments help overcome capital-market failures, exploit externalities, and invest in strategically important projects (e.g., Gerschenkron, 1962). According to this view, governments have adequate information and incentives to promote socially desirable investments.

Shleifer and Vishny (1998), in contrast, argue that governments do not have sufficient incentives to ensure socially desirable investments. Government ownership instead politicizes resource allocation, softens budget constraints, and hinders economic efficiency. Thus, government ownership facilitates the financing of politically attractive projects, not economically efficient ones.

In an influential study, LaPorta, Lopez-de-Silanes, and Shleifer (2002) piece together data on government ownership of banks from an assortment of sources. They find that countries with higher initial levels of government ownership tend to have subsequently less financial development and slower economic growth. In a related paper, Barth, Caprio, and Levine (2001a) use government ownership data from Bankscope and find that greater government ownership is generally associated with less efficient and less well-developed financial systems. The data used in both papers, however, do not cover all banks operating in a country and the degree of coverage varies across countries.

We make two improvements to existing studies of government-owned banks. First, we use data collected from national regulatory agencies. The data cover all banks and the definition of "government owned" is consistent across countries. Second, we control for differences in regulations and supervisory practices. Thus, we assess whether government ownership is associated with better banking-sector outcomes than private ownership with weak regulation and supervision.

\section{Data}

\section{III.A. Dataset}

We designed and implemented a survey funded by the World Bank to collect information on bank regulations and supervisory practices for 107 countries. Barth, Caprio, and Levine (2001b) describe the survey questions and data collection process in detail. The completion of the survey entailed numerous steps: collecting initial survey responses, reconciling conflicting responses from 
different officials in the same country, cross-checking the data with a survey by the Office of the Comptroller of the Currency (OCC), which included some overlap in the information requested, further reconciling any inconsistencies, and checking our data with information collected by the Institute of International Bankers, and the Financial Stability Forum's Working Group on Deposit Insurance, which provided input on the accuracy of responses for deposit insurance schemes. Thus, in numerous cases, we repeatedly communicated with authorities to obtain accurate information.

The regulatory and supervisory data are primarily from $1999 .{ }^{6}$ We frequently group the responses to individual questions into aggregate indexes that we define below. This paper uses those countries with more than one million people, but confirms the results when restricting the sample to countries with more than 200,000 people. We make the data available at the following website: www.worldbank.org/research/interest/intrstweb.htm.

\section{III.B. Variable Definitions}

Since Table 1 provides information on the data, sources, and specific survey questions used to construct the variables for this paper, we only briefly define them here in the text.

1. Bank Activity Regulatory Variables. We measure the degree to which national regulatory authorities allow banks to engage in the following three fee-based rather than more traditional interest-spread-based activities:

a. Securities Activities: the ability of banks to engage in the business of securities underwriting, brokering, dealing, and all aspects of the mutual fund industry.

b. Insurance Activities: the ability of banks to engage in insurance underwriting and selling.

c. Real Estate Activities: the ability of banks to engage in real estate investment, development, and management.

2. Mixing Banking / Commerce Regulatory Variables. We construct two measures of the degree of regulatory restrictiveness on the mixing of banking and commerce.

a. Banks Owning Nonfinancial Firms measures restrictions on the ability of banks to own and control nonfinancial firms.

b. Nonfinancial Firms Owning Banks measures restrictions on the ability of nonfinancial firms to own and control banks

\footnotetext{
${ }^{6}$ Of the 107 responses received, 13 were received in November 1998, 65 were received in 1999, and 29 in 2000 , with 19 of the latter received in either January or February.
} 
In addition, we also construct an overall bank restrictiveness variable as follows:

Restrictions on Bank Activities: includes restrictions on securities, insurance, and real estate activities plus restrictions on the banks owning and controlling nonfinancial firms.

\section{Competition Regulatory Variables.}

a. Limitations on Foreign Bank Entry/Ownership: whether there are any limitations placed on the ownership of domestic banks by foreign banks and whether there are any limitations placed on the ability of foreign banks to enter the domestic banking industry. If there are any limitations, this variable is assigned a value of 1 and a value of 0 otherwise.

b. Entry into Banking Requirements: measures the specific legal requirements for obtaining a license to operate as a bank.

c. Fraction of Entry Applications Denied: fraction of applications denied.

(1) Foreign Denials: fraction of foreign applications denied.

(2) Domestic Denials: fraction of domestic applications denied.

4. Capital Regulatory Variables. We use three measures of capital regulatory stringency.

a. Overall Capital Stringency measures the extent of regulatory requirements regarding the amount of capital banks must hold.

b. Initial Capital Stringency measures whether the source of funds that count as regulatory capital can include assets other than cash or government securities, borrowed funds, and whether the regulatory/supervisory authorities verify the sources of capital.

c. Capital Regulatory Index incorporates the previous two measures of capital stringency.

\section{Official Supervisory Action Variables.}

a. Official Supervisory Power measures the extent to which official supervisory authorities have the authority to take specific actions to prevent and correct problems.

We also decompose this variable into three constituent parts:

(1) Prompt Corrective Power measures the extent to which the law establishes predetermined levels of bank solvency deterioration that forces automatic enforcement actions, such as intervention, and the extent to which supervisors have the requisite, suitable powers to do so.

(2) Restructuring Power measures the extent to which supervisory authorities have the power to restructure and reorganize troubled banks.

(3) Declaring Insolvency Power measures the extent to which supervisory authorities have the power to declare a deeply troubled bank insolvent.

b. Supervisory Forbearance Discretion measures the degree to which supervisory authorities 
may engage in forbearance when confronted with violations of laws or regulations or with other imprudent behavior on the part of banks.

c. Loan Classification Stringency measures the degree to which loans that are in arrears must be classified as sub-standard, doubtful, or loss.

d. Provisioning Stringency measures the degree to which a bank must provision against a loan that is classified first as sub-standard, then as doubtful, and lastly as loss.

e. Diversification Index measures whether regulations support geographical asset diversification. It is based on two variables:

(1) Diversification Guidelines: whether there are there explicit, verifiable, and quantifiable guidelines for asset diversification.

(2) No Foreign Loans: whether banks are prohibited from making loans abroad.

6. Official Supervisory Experience and Structure. We attempt to measure the experience and structure of the supervisory regime with the following variables:

a. Supervisor Tenure: equals the average years of tenure of professional bank supervisors.

b. Independence of Supervisory Authority-Overall: measures the degree to which the supervisory authority is independent.

1. Independence of Supervisory Authority-Political: measures the degree to which the supervisory authority is independent from the government.

2. Independence of Supervisory Authority-Banks: measures the degree to which the supervisory authority is independent from lawsuits from banks and others.

c. Multiple Supervisors: indicates whether there is a single official regulatory of banks, or whether multiple supervisor share responsibility for supervising the nation's banks. This variable is assigned a value of 1 if there is more than one supervisor and 0 otherwise.

7. Private Monitoring Variables. We measure private-sector monitoring with four indicators.

a. Certified Audit Required: This variable captures whether an outside licensed audit is required of the financial statements issued by a bank. Such an audit would presumably indicate the presence or absence of an independent assessment of the accuracy of financial information released to the public.

b. Percent of 10 Biggest Banks Rated by International Rating Agencies: The percentage of the top 10 banks that are rated by international credit-rating agencies. The greater the percentage, the more the public may be aware of the overall condition of the banking industry as viewed by an independent third party.

c. No Explicit Deposit Insurance Scheme: takes a value of 1 if there is an explicit deposit insurance scheme, and 0 otherwise. Lower values indicate more private monitoring.

d. Bank Accounting: this variable takes a value of 1 when the income statement includes 
accrued or unpaid interest or principal on nonperforming loans and when banks are required to produce consolidated financial statements.

e. Private Monitoring Index: includes (a), (b) [which equals 1 if the percentage is 100; 0 otherwise], (c), and (d). In addition, three other measures are included in the index based on 'yes or no' answers. Specifically, a 1 is assigned if off-balance sheet items are disclosed to the public; if banks must disclose risk management procedures to the public; and if subordinated debt is allowable (required) as a part of regulatory capital. Higher values indicating more private oversight.

8. Deposit Insurance Scheme Variables. Three variables capture deposit insurance regime:

a. Deposit Insurer Power: based on the assignment of 1 (yes) or 0 (no) values to three questions assessing whether the deposit insurance authority has the authority: (1) to make the decision to intervene in a bank, (2) to take legal action against bank directors or officials, or (3) has ever taken any legal action against bank directors or officers. The sum of the assigned values ranges from 0 to 3, with higher values indicating more power.

b. Deposit Insurance Funds-to-Total Bank Assets: the size of the deposit insurance fund relative to total bank assets. In the case of the U.S. savings and loan debacle during the 1980 s, the insurance agency itself reported insolvency. This severely limited its ability to effectively resolve failed savings and loan institutions in a timely manner [Barth (1991)].

c. Moral Hazard Index: based on Demirgüç-Kunt and Detragiache (2002), who used principal components to capture the presence and design features of explicit deposit insurance systems, with the latter including: no coinsurance, foreign currency deposits covered, interbank deposits covered, type of funding, source of funding, management, membership, and the level of explicit coverage. Higher values imply greater moral hazard.

\section{Market Structure Indicators}

a. Bank Concentration: the fraction of deposits held by the five largest banks.

b. Foreign-Owned Banks: fraction of system's assets that are 50\% or more foreign owned.

c. Government-Owned Banks: fraction of system's assets 50\% or more government owned.

\section{Outcomes: ${ }^{7}$}

a. Bank Development: equals claims on the private sector by deposit money banks as a share of GDP and is the average value over the $1997-99$ period. $^{8}$

b. Net Interest Margin: equals net interest income divided by total assets, 1997.

c. Overhead Costs: equals total bank overhead costs as a share of total banks assets, 1997.

\footnotetext{
${ }^{7}$ For bank development, we update Levine, Loayza, and Beck, (2000). The net interest margin and overhead cost variables are from Beck, Demirgüç-Kunt, and Levine (2001). Nonperforming loans are from this paper's survey.

${ }^{8}$ We average over the $1997-99$ period to smooth business cycle fluctuations and obtain the same results using 1999 data.
} 
d. Nonperforming Loans: nonperforming loans as a share of total assets, 1999.

e. Crisis: whether a country suffered a major banking crisis according to Caprio-Klingebiel (1999) during the 1990s or late 1980s.

\section{III.C. Indexes}

We use two methods to construct indexes of regulations and supervisory practices that incorporate the answers to several questions from our survey, with the specific questions listed in Table 1. First, many of the questions can be specified as simple zero/one variables. Thus, our first method simply sums the individual zero/one answers. This method gives equal weight to each of the questions in constructing the index. The second method involves the construction of the first principal component of the underlying questions. In constructing this component, the factor analytic procedure produces a principal component with mean zero and standard deviation one. An advantage of this method is that equal weights for the individual questions are not specified. A disadvantage is that it is less transparent how a change in the response to a question changes the index.

We only report the results using the principal component indexes. Nevertheless, we have confirmed all this paper's conclusions using both methods.

\section{III.D. Summary Statistics}

There is great cross-country, cross-regional, and cross-income group diversity in bank regulatory and supervisory practices. For instance, many countries - such as Australia, Austria, Germany, India, Russia, the United Kingdom, and Zambia - impose no restrictions on the ability of banks to engage in securities activities (Securities Activities). In contrast, Cambodia, China, and Vietnam prohibit banks or their subsidiaries from conducting securities activities. More generally, poorer countries place tighter restrictions on bank activities than richer countries. Also, some countries during the year prior to the survey had no new banks, including Chile, Egypt, Korea, and Gambia. Other countries had more than 25 new banks, such as the United States, Italy, India, Switzerland, Netherlands, Japan, Germany, and Romania. Barth, Caprio, and Levine (2001b) illustrate additional cross-country differences.

This paper's main messages are contained in Table 2's correlations. These are as follows:

First, the percentage of the banking system owned by the government (Government-Owned 
Banks) is positively associated with tighter restrictions on bank activities (Restrictions on Bank Activities), positively associated with the percentage of entry applications denied (Entry Applications Denied), positively associated with prohibitions against making foreign loans (No Foreign Loans), and negatively associated with regulatory variables that promote private monitoring of banks (Private Monitoring Index). Thus, greater government ownership is associated with policies that restrict bank activities, reduce bank competition, erect barriers to international financial integration, and impede private-sector corporate control of banks. Such ownership is not associated with either stricter capital regulations (Capital Regulatory Index) or greater prompt corrective power (Prompt Corrective Power Index).

Second, we do not observe the simple regulatory/supervisory tradeoffs stressed by many theoretical models. For instance, we expected to find that countries that adopt generous deposit insurance regimes (high values of the Moral Hazard Index) would also have powerful official supervisors, extensive prompt corrective powers, stringent capital requirements, extensive private monitoring, and perhaps greater restrictions on bank activities to ameliorate the bad incentives associated with generous deposit insurance. We did not confirm these expectations, however. Although the generosity of the deposit insurance regime is significantly correlated with the stringency of capital regulations, it is not significantly correlated with indexes of Prompt Corrective Power, Official Supervisory Power, Private Monitoring, or Restrictions on Bank Activities. Similarly, we did not find that countries with higher levels of the Private Monitoring Index had correspondingly lower levels of Official Supervisory Power.

Third, while not uniform, the correlations suggest that countries tend to take either an open, private-sector oriented approach to regulation and supervision, or a more closed, governmentcontrolled approach. Thus, the Private Monitoring Index is negatively associated with the Entry into Banking Requirements Index, Restrictions on Bank Activities, and Government Ownership. In turn, the Entry Applications Denied is positively associated with Restrictions on Bank Activity and No Foreign Loans.

Fourth, the correlations are consistent with the view that countries with more open, privatesector-oriented approaches to regulation and supervision tend to have greater bank development, better performance and more stable banks. Specifically, better developed banks as measured by greater Bank Development are associated with higher levels of the Private Monitoring Index, fewer 
Restrictions on Bank Activities, less Prompt Corrective Power by supervisors, and lower levels of Government Ownership. Similarly, more efficient banking systems (as measured by lower levels of the Net Interest Margin index) are associated with higher levels of the Private Monitoring Index, fewer Restrictions on Bank Activities, and lower levels of Government Ownership. We also find that bank Overhead Costs are negatively correlated with (i) ease of bank entry (Entry into Banking Requirements Index), (ii) greater Private Monitoring, and (iii) less Government Ownership. Finally, Major Banking Crises are much more frequent in countries with generous deposit insurance (Moral Hazard Index) and extensive government ownership of the banking industry.

Fifth, the correlations are consistent with the view that government corruption (lower levels of Government Integrity) tends to be higher in countries where the government plays a large role in supervising, regulating, and owning banks. In particular, corruption is associated with powerful official supervision (Official Supervisory Power), weak private-sector monitoring, limited entry (Entry Applications Denied), restricted foreign loans, high levels of government ownership of banks, restricted bank activities, and weak capital regulations. ${ }^{9}$

These correlation results are informative but due to their bivariate nature they do not control for other aspects of regulation and supervision. We therefore explore whether these relationships change when simultaneously including a variety of regulations and supervisory practices.

\section{Regression Results}

\section{IV.A. Banking sector outcomes and regulation / supervision: Multivariate Analyses}

Tables 3 and 4 present our basic regression results when simultaneously including a wide range of bank regulation/supervision indicators. There are two types of regressions. First, we use ordinary least squares regressions to examine the relationships between bank outcomes and bank regulation and supervision. In these regressions, we regress each of the four outcome variables (Bank

\footnotetext{
${ }^{9}$ Note, in early versions of this paper, we examined whether particular types of regulations and supervisory practices are positively associated with government corruption. We did indeed find a very strong, positive relationship between corruption and countries with powerful supervisory agencies, tight restrictions on bank activities, entry barriers that limit competition and a negative relationship between corruption and countries that promote private-sector monitoring of banks when (i) controlling for many other country characteristics and (ii) using instrumental variables, but do not pursue this line of investigation here because it is tangential to the paper's main message.
} 
Development, Net Interest Margin, Overhead Costs, and Nonperforming Loans) on various supervisory and regulatory indicators. Since La Porta, Lopez-de-Silanes, Shleifer, and Vishny (1998) find that legal origin helps account for cross-country differences in financial development, we also include legal origin dummy variables as exogenous control variables. The legal origin variables jointly enter all of the Table 3 regressions significantly. The results do not depend on including these controls, however. Moreover we obtain the same results when controlling for religious composition and latitudinal distance from the equator, which some theories suggest influence financial development (Stulz and Williamson, 2002; Beck, Demirguc-Kunt, and Levine, 2002). ${ }^{10}$

Second, Table 4 presents logit regressions that examine the relationships between banking crises and bank regulation and supervision. Since many consider macroeconomic instability to be an important determinant of banking crises, we include the average inflation rate during the five years prior to the crisis in countries that experienced a banking crisis. In countries that did not, we include the average inflation rate during the five years prior to the survey, 1993-1997. In many cases, we include interaction terms to examine whether the association of one regulatory or supervisory indicator with bank stability depends on other aspects of regulation and supervision.

We organize the discussion around each of the specific issues discussed in Section II. Furthermore, in each case, we focus on only one or two key regulatory/supervisory variables. For example, when discussing banking powers, we focus on Restrictions on Bank Activities, which is an aggregate measure of restrictions on bank activities. Nevertheless, we examined each of the components of the indexes (see Appendix available on request). In cases where the individual components produce different results from the aggregate index, we discuss these below.

\footnotetext{
${ }^{10}$ There are five possible legal origins: English Common Law, French Civil Law, German Civil Law, Scandinavian Civil Code, and Socialist/Communist Law. To assess whether there is an independent association between bank development/performance and bank regulations and supervisory practices, we include dummy variables for each country's legal origin (except the Scandinavian law countries). Legal origin is the source of the Company Law or Commercial Code for each country. Note, due to data limitations, there are some regressions in which there are no Socialist legal origin countries. To measure religious composition, we the measure of the percentage of the population in each country that is Roman Catholic, Protestant, Muslim, or belongs to "other denominations." The numbers are in percent and sum to 100 (so we omit Protestant from the regressions). Latitude is measured as the (absolute value) of the latitudinal distance from the equator.
} 


\section{Regulations on bank activities and mixing banking-commerce}

Table 3 indicates that restricting bank activities is negatively associated with bank development, but there is not a robust link between regulatory restrictions on bank activities and net interest margins or overhead costs. The negative association between restrictions on bank activities and bank development holds while controlling for capital regulations, official supervisory power, the private-monitoring index, regulations on the entry of banks, and government ownership of banks. Bank development is a particularly important indicator because it is positively associated with economic growth (King and Levine, 1993a,b; Levine and Zervos, 1998; Levine, Loayza, and Beck, 2000).

The size of the coefficient is economically large. For instance, the coefficients suggest that in a country like Egypt that imposes tight restrictions on bank activities (i.e., its value is more than one standard deviation above the mean, 1.2) a loosening of these restrictions to the sample mean (0) is associated with an increase in bank development of 0.14(=1.2*0.118). This means Egypt's bank development increases from 0.49 to 0.63 , which is about the level in Italy (whose restrictions index equals the mean). We do not present this as an exploitable policy experiment but rather as an indicator of the economic size of the coefficient. We also examine the individual components of the aggregate Restrictions on Bank Activities index. The results indicate that restricting banks from engaging in securities activities is strongly, negatively associated with bank development.

The results also indicate that restricting bank activities is associated with an increase in the likelihood of suffering a major crisis (Table 4). In the full sample, we find a weak, positive relationship between the likelihood of a crisis and restricting bank activities (Regression 1). The ability of banks to stabilize income flows by diversifying activities, however, may only work in countries with sufficient securities market development. When restricting the sample to countries for which the World Bank has been able to collect at least some data on stock market transactions, we find that greater regulatory restrictions are indeed strongly, positively associated with the likelihood of suffering a crisis (Regression 2). The other regressions in Table 4 do not restrict the sample. Somewhat anomalously, regulatory restrictions on bank activities are not positively associated with non-performing loans. While diversifying across non-loan making activities is positively associated with bank stability (Table 4), diversification into non-loan making lines of business does not translate into higher quality loans (Table 3). In sum, while recognizing this result on non-performing loans, the crisis regressions are consistent with the view that diversification of income through nontraditional activities is positively 
associated with bank stability, especially in economies with active nonbank-financial markets. ${ }^{11}$

We examine whether restricting bank activities and the mixing of banking and commerce is associated with positive outcomes under specific conditions. For example, Boyd, Chang, and Smith's (1998) model predicts that restricting bank activities may reduce financial fragility in the presence of generous deposit insurance. Thus, we entered an interaction term into the regressions in Table 3 and Table 4 that equals Restrictions on Bank Activities * Moral Hazard Index, where Moral Hazard Index is the Demirgüç-Kunt and Detragiache (2002) measure of deposit insurance generosity. The conclusions do not change. Restrictions on Bank Activities retains its negative association with bank development, and its positive association with the likelihood of a crisis, while the interaction term is not significant. Similarly, some argue that in weak institutional environments - environments where the public sector lacks the ability to monitor banks (either because of weak Official Supervisory Powers, absence of Prompt Corrective Powers, or insufficient Capital Regulations) - it is important to restrict bank activities. When we include interaction terms for these variables, we again find no support for this contention. ${ }^{12}$ We do not find any support for more subtle theories regarding the efficacy of restricting bank activities. Thus, the bank fragility results remain broadly consistent with the view that there are diversification benefits from allowing banks to engage in non-traditional activities. These conclusions must be tempered, however, by the fact that with such diversification one would have expected to find a positive correlation between restrictions on bank activities and both overhead costs and nonperforming loans. But this is not the case (Table 3).

\footnotetext{
${ }^{11}$ We collected historical data on restrictions on bank activities. For each country that experienced a major banking crisis, we identified the country's policies toward bank activities prior to the crisis. Using pre-crisis policies strengths this paper's conclusions. The vast majority of countries that experienced a crisis did not change their policies. In the few cases that did change, virtually all of them changed toward removing restrictions on bank activities after the crisis. Thus, using current observations biases the results against those that we report (Barth, Caprio, and Levine, 2001a).

${ }^{12}$ We also experimented with an interaction term that equals Restrictions on Bank Activities * Corrupt. The reason is that some may argue that in corrupt environments it is important to limit the range of permissible bank activities. Our results do not support this suspicion. We continue to find a negative association between Restrictions on Bank Activities and both bank performance and stability when including Restrictions on Bank Activities*Corrupt, with this interaction term entering insignificantly. All these results are in an Appendix that is available upon request.
} 


\section{Regulations on domestic and foreign bank entry}

Table 3 indicates that tighter restrictions on entry into banking are positively associated with overhead costs, but there is not a significant link between entry restrictions on net interest margins. Furthermore, the relationship between overhead costs and restricting entry is economically small. For instance, a one standard deviation increase in the Entry into Banking Requirements Index is associated with an increase in Overhead Costs of only $0.003(=1 * 0.003)$, which is small insofar as the mean value is 0.039 and the standard deviation is $0.023 .{ }^{13}$

Table 4 indicates that in several regressions the likelihood of a major banking crisis is positively associated with greater Limitations on Foreign Bank Entry/Ownership. We find that foreignbank ownership per se is not associated with the likelihood of a crisis. Rather, it is limitations on foreign-bank entry and ownership that are positively associated with bank fragility.

We examine whether restricting bank entry is associated with favorable outcomes in particular environments. Specifically, we assess whether there are positive associations between bank outcomes and restricting bank entry - both domestic and foreign bank entry - with weak official supervision. We examine the following interaction terms: (Entry into Banking Regulations)*(Official Supervisory Power), (Limitations on Foreign Bank Entry/Ownership)*(Entry into Banking Regulations), and (Limitations on Foreign Bank Entry/Ownership)*(Official Supervisory Power). We find no evidence of favorable relationships between restricting bank entry and bank development, performance or stability under any of these conditions.

\section{Regulations on capital adequacy}

Table 3's results do not suggest a strong, independent relationship between capital regulatory stringency and bank development, net interest margins, or overhead cost when controlling for other regulations and supervisory practices. While capital stringency is positively correlated with bank development (Table 2), this relationship is not robust to controlling for other supervisory and regulatory policies. In terms of bank stability, there is a significantly negative relationship between

\footnotetext{
${ }^{13}$ Note, although regulatory restrictions on competition are significantly positively associated with overhead costs, we did not find a significant relationship between overhead costs and the actual level of bank concentration. Specifically, when we include bank concentration in the Table 3 regressions instead of the Entry into Banking Requirements Index, bank concentration is not significantly associated with overhead costs.
} 
capital stringency and nonperforming loans. However, when examining banking crises, there are some specifications in which capital stringency enters with a negative and significant coefficient (Table 4). Yet, alterations in the conditioning information set suggest that this relationship is not very robust. Thus, the evidence is somewhat mixed. While more stringent capital regulations are associated with fewer nonperforming loans, capital stringency is not robustly linked with banking crises or bank development or efficiency when controlling for other supervisory/ regulatory policies.

As we discussed above, there is a rich theoretical literature on bank capital requirements indicating that particular settings influence their desirability and effect. Consequently, we also examine whether more stringent requirements are positively associated with favorable banking-sector outcomes in particular regulatory/supervisory environments. In particular, strict capital adequacy regulations may be especially important in countries with generous deposit insurance schemes. We find no evidence for the proposition that capital regulations ameliorate the risk-taking incentives produced by generous deposit insurance (see regression 9, Table 4). Similarly, capital regulations may be especially important in countries with weak Official Supervisory Powers, or a regulatory environment that does not spur Private Monitoring. Yet, when we include these interaction terms, we find no evidence for these more subtle theories of the effectiveness of capital regulation.

These results do not suggest that bank capital is unimportant for bank fragility. They do, however, suggest that there is not a strong relationship between the stringency of official capital requirements and the likelihood of a crisis after controlling for other features of the regulatory and supervisory regime. These results may help inform the evolution of the Basel II Capital Accord.

\section{Deposit insurance design}

We find a positive association between the generosity of the deposit insurance scheme and bank fragility (Table 4). This is consistent with recent work by Demirgüç-Kunt and Detragiache (2002). The positive relationship, moreover, is robust to alterations in the control variables as we show below. This result is consistent with the view that deposit insurance not only substantially aggravates moral hazard but also produces deleterious effects on bank stability. ${ }^{14}$

\footnotetext{
${ }^{14}$ We examined the link between the moral hazard index and bank development, though this is not shown in Table 3 to save space. We did not find a strong association between the generosity of the deposit insurance system (Moral Hazard Index)
} 
Importantly, Demirgüç-Kunt and Detragiache (2002) use annual data to show that deposit insurance generosity predicts future banking crises. They, however, were unable to control for other features of the regulatory/supervisory environment because these data were unavailable. We find that deposit insurance generosity is positively associated with the likelihood of a crisis while controlling for many features of regulation and supervision. Given that we do not have time-series data, however, we are not able to assess whether deposit insurance generosity predicts future banking crises.

The relationship between deposit insurance and bank fragility is economically large. For instance, using regression 3 (Table 4) we can compute the drop in the probability of a banking crisis for Mexico. When its quite generous deposit insurance scheme (3.9) is reduced to the sample mean of 0 , then Mexico's probability of a crisis falls by 12 percentage points, using Mexico's values for all the variables in regression 3. Again, we stress that our study does not identify an exploitable relationship. This illustrative example simply confirms the Demirguc-Kunt and Detragiache (2002) conclusion that the adverse incentive effects created by generous schemes may be economically substantial.

Some suggest that strong official oversight and stringent capital requirements can mitigate the moral hazard created by a generous deposit insurance scheme. Others disagree, believing these do not work. We find that official supervisory power and tighter capital regulations do not mitigate the negative relationship between generous deposit insurance and bank fragility (Table 4). However, better-developed private property rights - as proxied by greater adherence to the rule of law (Rule of Law) - and greater political openness (Political Openness) do mitigate the negative association of moral hazard and bank fragility. ${ }^{15}$ It is worth noting, however, that the generosity of deposit insurance is positively associated with the probability of suffering a crisis even in countries with the highest Rule of Law values (e.g., the cross-over point is Rule of Law $=7.4$, but the maximum Rule of Law value is 6). Thus, while greater Rule of Law reduces the negative association of generous deposit insurance, it does not eliminate it. Furthermore, while many stress tighter official supervision and more stringent capital requirements as the antidote to generous deposit insurance, we find little evidence to support this advice.

and bank development or efficiency. Later, when using instrumental variables, we present these results (Table 5).

${ }^{15}$ The Rule of Law is an indicator of the degree to which the country adheres to the rule of law. It ranges from 0 to 6 with higher values indicating greater confidence in the legal system to settle disputes. It is obtained from the International Country Risk Guide and is averaged over 1990-1999. 


\section{Supervision}

We do not find a strong association between bank development and performance and official supervisory power (see Table 3). Specifically, the overall official supervisory power indicator is not related to bank development or bank efficiency or the level of nonperforming loans. Declaring insolvency power is also unrelated to development or efficiency. The prompt corrective power indicator is negatively related to bank development (but these results are not robust to changes in the conditioning information set or to controlling for the degree of political openness). ${ }^{16}$ There is also some weak evidence that supervisory forbearance discretion is positively related to bank efficiency (but this is not robust either). There is, however, a positive association between supervisory tenure and bank development. Supervisory independence, loan classification stringency, liquidity requirements, diversification guidelines, and restrictions on making loans abroad are not related to bank development or efficiency or the level of nonperforming loans. In sum, those features that constitute official "core" supervision are not strongly associated with bank development, bank efficiency, and the level of nonperforming loans in a convincing manner.

In terms of banking crises, the same basic message emerges with only one exception (Table 4). Official supervisory powers - and the assortment of Official Supervisory Action Variables and Official Supervisory Experience and Structure Variables defined above - are not statistically related to the probability of suffering a systemic crisis.

The one exception involves the diversification index (which aggregates diversification guidelines and the absence of restrictions on making loans abroad). There is a negative relationship between the diversification index and the likelihood of suffering a major crisis in small economies.

\footnotetext{
${ }^{16}$ Additional results, available upon request, indicate that Official Supervisory Power has less of a negative relationship to bank development in politically open economies (i.e., those countries is which the government does not repress the media and there is greater private-sector ownership of the media). The results imply that in a country like Korea with an intermediate level of political openness (Political Openness is approximately 0), a one standard deviation increase in Official Supervisory Power would be associated with a decrease in bank development of $0.09(=1 * 0.092)$. This is a large enough change to move from Korea's high level of bank development (0.73) down toward that of Chile's (0.63), which is near the sample average. In contrast, the same increase in official supervisory power in France (where the Political Openness variable equals 2.7$)$ would actually be associated with an increase in bank development, $+0.07(=-0.09 * 1+$ $\left.0.06^{*} 2.7 * 1\right)$. Thus, official supervisory power is particularly harmful to bank development in countries with closed political systems. This raises a cautionary flag toward current efforts by international financial institutions to boost supervisory power in developing countries. However, Political Openness does not mitigate the pernicious effect of any of the other regulatory/supervisory variables, such as Restrictions on Bank Activities, Prompt Corrective Action Power, No Foreign Loans, or Government Ownership of Banks. The political openness variable is based on the openness of the media, both print and broadcast.
} 
Specifically, we include the diversification index and an interaction term. The interaction term equals the diversification index multiplied by the logarithm of real per capita GDP in 1995 (these are Purchasing Power Parity adjusted figures from the Penn World Tables.). As shown in Table 4, diversification is negatively associated with the likelihood of a crisis but diversification guidelines have less of a stabilizing effect in bigger countries. The cut-off is high; diversification guidelines have stabilizing effects in all but the nine largest countries.

One may, of course, argue that we do not have sufficiently detailed information on: (a) regulations and supervisory practices, (b) their actual implementation (except that independence may proxy for the vigor with which policies are implemented), or (c) the transparency and accountability of the regulatory/supervisory process to evaluate cross-country differences in regulation and supervision. While sympathetic to this criticism, we do note that this paper's data on regulations and supervisory practices is more extensive than any existing study. Thus, while by no means definitive, these initial findings augment our understanding of the relationships between bank supervision and regulation and banking sector development, performance, and stability.

\section{Regulations on easing private-sector monitoring of banks}

Private monitoring is strongly, positively associated with bank development and negatively associated with net interest margins and the level of nonperforming loans (Table 3). While private monitoring is negatively correlated with overhead costs (Table 2), the link between private monitoring and overhead costs is not robust to controlling for other regulatory and supervisory policies (Table 3 ). The relationship between bank development and private monitoring seems economically large. For instance, a one standard deviation increase in the Private Monitoring Index in a country like Bangladesh with both weak private monitoring and low bank development $(0.28)$, is associated with an increase in bank development of about $32 \%(=(0.09 * 1 / 0.28) * 100)$. We again stress the purely illustrative nature of this experiment. There is a negative association between private monitoring and overhead costs, but it becomes insignificant when controlling for government ownership.

In terms of crises, there is no significant association between private-sector monitoring and the likelihood of a banking crisis when controlling for other variables (Table 4). Since capital regulations are a possible vehicle for encouraging prudent behavior by banks, we decided to exclude the capital regulation index from the crisis regressions. Eliminating this index does not change the results, 
however. This finding is contrary to predictions about the positive role of private-sector monitoring in fostering banking stability and a puzzle given the positive link between private-sector monitoring and banking sector development (Table 3).

The results are consistent with view that those countries facilitating private-sector monitoring of banks have better performing banks than those less focused on empowering private-sector corporate control of banks. This is consistent with the goal of the third pillar in the Basel II Capital Accord. However, we did not find a robust link between private-sector monitoring and bank fragility. While recognizing this puzzle, the results, taken together with those of official supervisory power, are less consistent with theories emphasizing direct government oversight and more consistent with theories emphasizing private-sector corporate control.

\section{Government ownership of banks}

Table 3 indicates that government ownership is positively related to the level of nonperforming loans but not robustly linked with the other indicators of bank development and performance when controlling for bank regulation and supervision. We also do not find a strong, positive relationship between government ownership and the likelihood of a crisis (Table 4). These results do not confirm those in Caprio and Martinez (2000), who find that government ownership is significantly associated with increases in bank fragility using panel data. Due to data limitations, they are unable to control for other features of regulation and supervision. In contrast to their work, however, while we control for other features, we have only examined cross-country relationships because we do not have time-series observations on the regulatory and supervisory variables.

Overall, we do not find that greater government ownership of banks is associated with lower banking sector development, efficiency, and stability when controlling for the regulatory and supervisory environment (Table 3). We do, however, find a strong negative correlation between government ownership and bank development, efficiency, and stability (Table 2). ${ }^{17}$ These results suggest that the bank regulations and supervisory practices are closely associated with the degree of government ownership of banks. Thus, when we include regulations and supervisory practices

\footnotetext{
${ }^{17}$ Note, in a simple regression of bank development or efficiency on government ownership while controlling for the legal origins dummy variables, government ownership enters significantly.
} 
together in the same regression with government ownership, the induced multi-collinearity produces insignificant coefficients on government ownership. This is supported by our earlier finding that government ownership is positively associated with tighter restrictions on bank activities, restrictions on bank entry, prohibitions on foreign loans, and negatively associated with private-monitoring.

\section{IV.B. Bank development and regulation / supervision: Causality Issues}

The empirical results from the simple correlations and multivariate regressions do not control for the potential endogeneity of bank regulations and supervisory practices. To control for potential simultaneity bias, we use instrumental variables to identify the exogenous component of supervision and regulation. Given the paucity of instruments and the extensive list of regulations and supervisory practices examined, we consider each regulatory and supervisory sequentially. That is, instead of the multivariate analyses presented in Table 3, we regress bank development on each regulatory and supervisory indicator while instrumenting for the regulation or supervision indicator.

To select instrumental variables for the regulatory and supervisory variables, we use theory and recent empirical work. First, some argue that religious composition may shape governmental approaches to regulation and supervision. According to Landes (1998), the Catholic and Muslim religions tend to generate hierarchical bonds of authority that shape the structure of government institutions. Stulz and Williamson (2002) provide empirical support for this view. Thus, we include measures of religious composition as instrumental variables. Second, as discussed and tested in Beck, Demirguc-Kunt, and Levine (2002) and Easterly and Levine (2002), some argue that countries in poor climates - tropical climates - tend to produce exploitative political regimes that gear governmental institutions toward protecting a small elite. Thus, endowments may influence a broad array of institutions, including bank regulatory and supervisory institutions. We use latitudinal distance from the equator an instrument. Finally, legal origin variables are included as instruments. LLSV (1998) argue that civil law and socialist law countries will tend to support stronger governments relative to private property to a greater degree than common law countries. Thus, legal origin may also influence a country's approach to bank regulation and supervision. These instrumental variables are defined above. Critically, the first stage regressions always reject the null hypothesis that they do not explain any of the cross-country variation in the regulatory and supervisory variables. Thus, these instrumental variables explain cross-country variation in bank regulations and supervisory practices. 
Testing the validity of the instruments is crucial to ascertaining the consistency of the parameter estimates. Specifically, we use a generalized method of moments (GMM) estimator (Twostage least squares produce the same results) that is robust to heteroskedasticity. The GMM estimator amounts to imposing the set orthogonality conditions that the instrumental variables are uncorrelated with the error term. The economic meaning of these conditions is that the instrumental variables only affect the dependent variable through the explanatory variables. In the context of the Table 5 regressions, this implies that the instrumental variables affect bank development only through the bank regulatory/supervisory variables. We test this condition. The Hansen (1982) test of the overidentifying restrictions (OIR-test) assesses whether the instrumental variables are associated with bank development beyond their ability to explain bank regulations or supervisory practices. The test statistic is simply the sample size times the value attained for the objective function at the GMM estimate. Under the null hypothesis that the instruments are not correlated with the error term, the test is distributed as $\chi^{2}$ with degrees of freedom equal to the number instruments minus the number of regressors. If the data do not reject the null hypothesis-if the specification passes the OIR-test - then the data do not reject the validity of the instrumental variables. That is, failure to reject the OIR-test implies a failure to reject the estimated coefficient on bank regulation/supervision as indicating an effect running from bank regulation/supervision to bank development.

Table 5 presents the instrumental variable results. They confirm three major findings from Table 3's ordinary least squares multivariate analysis: (a) restrictions on bank activities are negatively associated with bank development, (b) regulations that boost private monitoring are positively associated with bank development, and (c) the Official Supervisory Power index is not significantly linked with bank development. Furthermore, the regressions do not reject the test of the overidentifying restrictions; thus, the data do not reject the validity of the instruments. Also, the instruments significantly account for cross-country variation in the supervisor/regulatory indicators in the first-stage regressions. When moving from the multivariate approach that simultaneously controls for many regulatory/supervisory features to the bivariate, instrumental variable analyses in Table 5, some differences emerge. Table 5 indicates that when we do not control for many regulatory/supervisory characteristics, we find that (1) limitations on foreign bank entry and the more frequently denial of entry applications are associated with poor bank development, (2) more stringent capital requirements are associated with higher levels of bank development, (3) prompt corrective action power, restrictions on foreign loans, and government ownership of bank are all negatively 
associated with bank development. ${ }^{18}$ These results emphasize that regulation/supervision cannot be taken in isolation. In terms of the stringency of capital requirements, Table 5 indicates a positive link between capital requirements and bank development when not controlling for other policies. However, the (a) positive correlation between capital requirements and regulations that promote private-sector monitoring and the (b) negative correlation between capital requirements and restrictions on bank activities (Table 2) imply that the stringency of capital regulations do not enjoy an independent link with bank development when controlling for these other policies (Table 3). More broadly, government ownership of banks is positively associated with the restrictions on the denial of entry into banking and prohibitions on making loans abroad and negatively associated with regulations that foster privatemonitoring (Table 2), so that government ownership does not enter into the multivariate regression significantly (Table 4) but does enter the bivariate regression significantly (Table 5).

Thus, this attempt to control for simultaneity does not substantively alter the tentative interpretation of our findings: countries that adopt an approach to bank regulation and supervision that spurs private-sector monitoring enjoy greater bank development than those that adopt an approach that stresses official restrictions on banks, powerful official oversight of banks, or government ownership of banks. We recognize, however, that the power of the OIR-test is weak because it is based on a failure to reject a null hypothesis. Thus, we believe that future microeconomic-based evidence that (a) more powerfully deals with simultaneity and (b) provides more precise measures of bank performance will greatly enhance our understanding of the causal relationship between bank regulation and supervision and banking sector outcomes.

\footnotetext{
${ }^{18}$ Note, the differences between the bivariate, instrumental variable results in Table 5 and the multivariate OLS results in Table 3 are due to the change from a multivariate to a bivariate set-up. In particular, applying OLS instead of instrumental variables to Table 5 produces very similar results to those reported in Table 3 (available on request). Thus, the differences between Table 3 and 5 reflects the simultaneous inclusion of many regulatory/supervisory variables.
} 


\section{Conclusions}

This paper examines the relationships between a broad array of bank regulations and supervisory practices and bank development, performance and stability. We conduct this analysis using our unique cross-country database that allows us to assess these interconnected relationships simultaneously. Although causality issues remain, the paper nonetheless provides some new, tentative empirical evidence on a range of contentious policy issues and theoretical debates.

First, restricting bank activities is negatively associated with bank development and stability, as compared to when banks can diversify into other financial activities. While theory provides conflicting predictions about the implications of restricting the range of bank activities, the results are consistent with the view that broad banking powers allow banks to diversify income sources and enhance stability. As noted, restrictions on bank activities are not positively associated with non-performing loans. While diversifying across non-loan making activities is not associated with higher loan quality, the results are consistent with the view that diversification of income through nontraditional activities is positively associated with bank stability. This finding, moreover, does not appear to be due to reverse causality, though much more work needs to be done in this regard. Furthermore, since we control for official supervisory practices, capital regulations, regulations on competition, government ownership of banks, and the moral hazard engendered by generous deposit insurance schemes, the negative relationship between restricting bank activities and bank development and stability does not seem to be due to an obvious omitted variable. Furthermore, we find no evidence that restricting bank activities is positively associated with favorable banking-sector outcomes in particular regulatory/supervisory environments. Specifically, we do not find positive relationships between bank development or stability and restrictions on bank activities in economies that offer more generous deposit insurance, have weak official supervision, ineffective incentives for private monitoring, or that lack stringent capital standards. These results must be qualified, however. We do not find that restricting bank activities is positively associated with overhead costs or nonperforming loans.

Second, although we do not find a strong association between restrictions on bank entry and bank efficiency, the results indicate that barriers to foreign-bank entry are positively associated with bank fragility. Critically, it is not the actual level of foreign presence (or bank concentration) that matters. Instead, it is specific impediments to bank entry that are associated with bank fragility. Finally, even when using interaction terms for numerous institutional, regulatory, and policy 
environments, we were not able to identify conditions that produced a positive relationship between restrictions on bank entry and banking sector outcomes.

Third, while the stringency of capital regulations is positively correlated with bank development, stringent capital regulations are not closely associated with bank development, performance or stability when controlling for other features of the bank regulation and supervision. This is consistent with recent studies that offer a cautious assessment of the independent beneficial effects of capital regulations. A cautionary note is worth raising, however. While we do not find a significant, negative relationship between capital regulations and banking crises, bank development, or bank efficiency, we do find that more stringent capital regulations are negatively linked with nonperforming loans. We also examined whether capital regulations are particularly important in countries with generous deposit insurance, weak official supervisory agencies, or ineffective regulations concerning private-sector monitoring of banks. We find no evidence that capital regulations are positively related to favorable banking-sector outcomes in particular institutional or policy environments.

Fourth, generous deposit insurance schemes are strongly and negatively associated with bank stability. Many believe that effective regulation and supervision can mitigate the moral hazard produced by generous deposit insurance. However, strong official supervisory agencies, stringent capital standards, and regulations that encourage private-sector monitoring of banks are not found to counterbalance these negative associations of generous deposit insurance.

Fifth, with but one exception, we do not find a strong relationship between a range of official supervisory indicators and bank performance and stability. Thus, measures of supervisory power, resources, independence, loan classification stringency, provisioning stringency, and others are not robustly associated with bank development, performance or stability. Again, these results do not support the strategies of many international agencies that focus on greater official supervisory oversight of banks. The one exception involves diversification. There is a negative relationship between the diversification index (which aggregates diversification guidelines and the absence of restrictions on making loans abroad) and the likelihood of suffering a major crisis, especially in small economies. The old adage, “don't put all your eggs in one basket," remains relevant for modern banking policy. 
Sixth, regulations that encourage and facilitate private monitoring of banks are associated with better banking-sector outcomes, i.e., greater bank development, lower net interest margins, and small nonperforming loans. This holds even when controlling for many other institutional and policy features. However, we did not find that regulations that foster private monitoring reduce the likelihood of suffering a major banking crisis.

Finally, while government ownership of banks is negatively correlated with favorable banking outcomes and positively linked with corruption, government ownership of banks does not retain and independent, robust association with bank development, efficiency, or stability when controlling for other features of the regulatory and supervisory environment. There is no evidence, even in weak institutional settings, that government-owned banks are associated with positive outcomes.

In terms of broad implications, these findings raise a cautionary flag regarding reform strategies that place excessive reliance on countries adhering to an extensive checklist of regulations and supervisory practices that involve direct, government oversight of and restrictions on banks. Instead, our findings are consistent with the view that regulations and supervisory practices that (1) force accurate information disclosure, (2) empower private-sector corporate control of banks, and (3) foster incentives for private agents to exert corporate control work best to promote bank development, performance and stability. Our results do not suggest that official regulation and supervision are unimportant. Indeed, the paper stresses that regulations and supervisory practices that force accurate information disclosure and limit the moral hazard incentives of poorly designed deposit insurance schemes are positively associated with greater bank development, better performance and increased stability. As emphasized and discussed in the Introduction, much work remains. By constructing a new database and conducting some initial analyses, this paper hopes to contribute to our understanding of the supervision and regulation of banks. 


\section{References}

Barth, J.R. (1991). The Great Savings and Loan Debacle, The AEI Press: Washington, D.C.

Barth, J.R., G. Caprio Jr., and R. Levine. (2001a). "Banking Systems Around the Globe: Do Regulations and Ownership Affect Performance and Stability?" in Frederic S. Mishkin, Editor: Prudential Supervision: What Works and What Doesn't, University of Chicago Press, 2001.

Barth, J.R., G. Caprio Jr., and R. Levine (2001b). "The Regulation and Supervision of Bank Around the World: A New Database," in Robert E. Litan and Richard Herring, Editors, Integrating Emerging Market Countries into the Global Financial System, Brookings-Wharton Papers on Financial Services, Brookings Institution Press.

Beck, T., Demirgüç-Kunt, A., Levine, R., (2001). The financial structure database. In Demirguc-Kunt, A., Levine, R. (Eds.) Financial Structure and Economic Growth: A Cross-Country Comparison of Banks, Markets, and Development, MIT Press, Cambridge, MA, pp. 17-80.

Beck, T., A. Demirgüç-Kunt, and R. Levine (2002). “Law, Endowments, and Finance,” Journal of Financial Economics, forthcoming.

Berger, A. N; R. S Demsetz, and P.E. Strahan (1999). "The Consolidation of the Financial Services Industry: Causes, Consequences, and Implications for the Future," Journal of Banking and Finance 23, 135-194.

Berger, A. N., R. J. Herring, and G. P. Szegö (1995). "The Role of Capital in Financial Institutions," Journal of Banking and Finance 19, 257-276.

Blum, J. (1999). “Do Capital Adequacy Requirements Reduce Risks in Banking?” Journal of Banking \& Finance 23, 755-771.

Boot, A.W.A. and A.V. Thakor (1997). "Financial System Architecture,” Review of Financial Studies 10(3), Fall, 693-733.

Boot, A.W.A. and A.V. Thakor (2000). “Can Relationship Banking Survive Competition?” Journal of Finance 55(2), April, 679-713.

Boyd, J. H.; C. Chang, and B.D. Smith (1998). "Moral Hazard Under Commercial and Universal Banking," Journal of Money, Credit, and Banking 30(3.2), 426-468.

Boyd, J.H.; S. Kwak, and B.D. Smith (2000). "Banking Crises : What Comes After?," University of Minnesota (Carlson School of Management), Department of Finance, mimeo.

Caprio, G. Jr., and D. Klingebiel (1999). "Episodes of Systemic and Borderline Financial Crises," World Bank, mimeo.

Caprio, G. Jr., and Martinez (2000). “Avoiding Disaster: Policies to Reduce the Risk of Banking Crises," World Bank mimeo and Egyptian Center for Economic Studies Working Paper No. 47.

Claessens, S. and D. Klingebiel (2000). “Competition and Scope of Activities in Financial Services," 
Washington D.C.: World Bank, mimeo, April.

Demirgüç-Kunt, A. and E. Detragiache (2002). Does Deposit Insurance Increase Banking System Stability? An Empirical Investigation,” Journal of Monetary Economics, forthcoming.

Dewatripont, M. and J. Tirole (1994). The Prudential Regulation of Banks, Cambridge: MIT Press.

Djankov, S., R. La Porta, F. Lopez-de-Silanes, A. Shleifer (2002). “The Regulation of Entry,” Quarterly Journal of Economics, 117, 1-37.

Easterly, W. and R. Levine (2002). "Tropics, Germs, and Crops: How Endowments Influence Economic Development," Journal of Monetary Economics, forthcoming.

Gerschenkron, A. (1962). Economic Backwardness in Historical Perspective: A Book of Essays. Cambridge, Mass.: Belknap Press of Harvard University Press.

Greenspan, A. (1998). “The Role of Capital in Optimal Banking Supervision and Regulation,” in Federal Reserve Bank of New York, "Financial Services at the Crossroads: Capital Regulation in the Twenty-First Century, Proceedings of a Conference," FRBNY Economic Policy Review 4:3, October.

Hansen, L.P. (1982). "Large Sample Properties of Generalized Method of Moment Estimators," Econometrics, 50, 1029-1054.

John, K.; T.A. John and A. Saunders (1994). “Universal Banking and Firm Risk Taking,” Journal of Banking and Finance 18, 307-23.

Keeley, M. C. (1990). "Deposit Insurance, Risk, and Market Power in Banking,” American Economic Review 80:5, 1183-1200.

Keeley, M.C., and F. T. Furlong (1990). "A Reexamination of Mean-Variance Analysis of Bank Capital Regulations." Journal of Banking and Finance 14, 69-84.

King, R. G., and R. Levine (1993a). "Finance and Growth: Schumpeter Might Be Right,” Quarterly Journal of Economics 108, 717-38.

King, R. G., and R. Levine (1993b). "Finance, Entrepreneurship, and Growth: Theory and Evidence," Journal of Monetary Economics 32, 513-42.

Kim, D. and A. M. Santomero (1988). "Risk in Banking and Capital Regulation.” Journal of Finance 35, 1219-1233.

Koehn, M. and A. M. Santomero (1980). "Regulation of Bank Capital and Portfolio Risk.” Journal of Finance 35, 1235-1250.

Landes, D. (1998). The Wealth and Poverty of Nations (W.W. Norton, New York, NY).

La Porta, R.; Lopez-de-Silanes, F.; and Shleifer, A. (2002). "Government Ownership of Commercial Banks", Journal of Finance, 57(1), 265-301. 
La Porta, R.; Lopez-de-Silanes, F.; Shleifer, A.; and Vishny, R. W. (1998). "Law and Finance," Journal of Political Economy, 106(6), pp. 1113-1155

Levine, R.; N. Loayza, and T. Beck (2000). "Financial Intermediation and Growth: Causality and Causes," Journal of Monetary Economics.

Levine, R., and S. Zervos (1998). "Stock Markets, Banks, and Economic Growth," American Economic Review 88, 537-558.

Levine, R. (1997). "Financial Development and Economic Growth: Views and Agenda," Journal of Economic Literature 35, 688-726.

Mullins, M. H., and D. H. Pyle (1994). "Liquidation Costs and Risk-Based Bank Capital," Journal of Banking and Finance 18, 113-138.

Pigou, Arthur C. (1938). The Economics of Welfare, $4^{\text {th }}$ Edition. London: MacMillan $\&$ Co.

Quintyn, Marc, and Michael Taylor, (2002). Regulatory and Supervisory Independence and Financial Stability, International Monetary Fund Working Paper No. 02/46, March.

Santos, J.A.C. (2001). "Bank Capital Regulation in Contemporary Banking Theory: A Review of the Literature," Financial Markets, Institutions and Instruments 10(2), 41-84.

Saunders. A. (1985) "Conflicts of Interest: An Economc View", in I. Walter (Ed.), Deregulating Wall Street: Commercial Bank Penetration of the Corporate Securities Market, (New York: John Wiley \& Sons), 207-30.

Shleifer, A. and R. Vishny (1998). The Grabbing Hand: Government Pathologies and their Cures, Cambridge, MA: Harvard University Press.

Stulz, R. and R. Williamson (2002). Culture, openness, and finance. Journal of Financial Economics, forthcoming.

Stigler, G.J. (1971). "The Theory of Economic Regulation," Bell Journal of Economics and Management Science 2, 3-21. 
Table 1

Information on Bank Regulatory, Supervisory and Deposit Insurance Variables

\begin{tabular}{|c|c|c|c|}
\hline Variable & Definition & Source and Quantification & World Bank Guide Questions \\
\hline \multicolumn{4}{|l|}{ 1. Bank Activity Regulatory Variables } \\
\hline (a) Securities Activities & $\begin{array}{l}\text { The extent to which banks may engage in } \\
\text { underwriting, brokering and dealing in securities, and } \\
\text { all aspects of the mutual fund industry. }\end{array}$ & $\begin{array}{l}\text { OCC and WBG } 4.1 \text { (higher values, more restrictive) } \\
\text { Unrestricted = } 1=\text { full range of activities can be } \\
\text { conducted directly in the bank; Permitted }=2=\text { full } \\
\text { range of activities can be conducted, but some or all } \\
\text { must be conducted in subsidiaries; Restricted }=3= \\
\text { less than full range of activities can be conducted in } \\
\text { the bank or subsidiaries; and Prohibited }=4=\text { the } \\
\text { activity cannot be conducted in either the bank or } \\
\text { subsidiaries. }\end{array}$ & $\begin{array}{l}4.1 \text { What is the level of regulatory restrictiveness for bank } \\
\text { participation in securities activities (the ability of banks to engage } \\
\text { in the business of securities underwriting, brokering, dealing, and } \\
\text { all aspects of the mutual fund industry)? }\end{array}$ \\
\hline (b) Insurance Activities & $\begin{array}{l}\text { The extent to which banks may engage in insurance } \\
\text { underwriting and selling. }\end{array}$ & $\begin{array}{l}\text { OCC and WBG } 4.2 \text { (higher values, more restrictive) } \\
\text { Unrestricted = } 1=\text { full range of activities can be } \\
\text { conducted directly in the bank; Permitted }=2=\text { full } \\
\text { range of activities can be conducted, but some or all } \\
\text { must be conducted in subsidiaries; Restricted }=3= \\
\text { less than full range of activities can be conducted in } \\
\text { the bank or subsidiaries; and Prohibited }=4=\text { the } \\
\text { activity cannot be conducted in either the bank or } \\
\text { subsidiaries. }\end{array}$ & $\begin{array}{l}\text { 4.2 What is the level of regulatory restrictiveness for bank } \\
\text { participation in insurance activities (the ability of banks to engage } \\
\text { in insurance underwriting and selling)? }\end{array}$ \\
\hline (c) Real Estate Activities & $\begin{array}{l}\text { The extent to which banks may engage in real estate } \\
\text { investment, development and management. }\end{array}$ & $\begin{array}{l}\text { OCC and WBG } 4.3 \text { (higher values, more restrictive) } \\
\text { Unrestricted }=1=\text { full range of activities can be } \\
\text { conducted directly in the bank; Permitted }=2=\text { full } \\
\text { range of activities can be conducted, but some or all } \\
\text { must be conducted in subsidiaries; Restricted }=3= \\
\text { less than full range of activities can be conducted in } \\
\text { the bank or subsidiaries; and Prohibited }=4=\text { the } \\
\text { activity cannot be conducted in either the bank or } \\
\text { subsidiaries. }\end{array}$ & $\begin{array}{l}\text { 4.3 What is the level of regulatory restrictiveness for bank } \\
\text { participation in real estate activities (the ability of banks to engage } \\
\text { in real estate investment, development, and management)? }\end{array}$ \\
\hline \multicolumn{4}{|c|}{ 2. Mixing Banking / Commerce Regulatory Variables } \\
\hline (a) Bank Owning Nonfinancial Firms & $\begin{array}{l}\text { The extent to which banks may own and control } \\
\text { nonfinancial firms. }\end{array}$ & $\begin{array}{l}\text { OCC and WBG } 4.4 \text { (higher values, more restrictive) } \\
\text { Unrestricted = } 1=\text { a bank may own } 100 \text { percent of } \\
\text { the equity in any nonfinancial firm; Permitted }=2=a \\
\text { bank may own } 100 \text { percent of the equity of a } \\
\text { nonfinancial firm, but ownership is limited based on } \\
\text { a bank's equity capital; Restricted }=3=\text { a bank can } \\
\text { only acquire less than } 100 \text { percent of the equity in a } \\
\text { nonfinancial firm; and Prohibited }=4=\text { a bank may } \\
\text { not acquire any equity investment in a nonfinancial } \\
\text { firm. }\end{array}$ & $\begin{array}{l}\text { 4.4 What is the level of regulatory restrictiveness for bank } \\
\text { ownership of nonfinancial firms? }\end{array}$ \\
\hline
\end{tabular}


Table 1

Information on Bank Regulatory, Supervisory and Deposit Insurance Variables

\begin{tabular}{|c|c|c|c|}
\hline Variable & Definition & Source and Quantification & World Bank Guide Questions \\
\hline (b) Nonfinancial Firms Owning Banks & $\begin{array}{l}\text { The extent to which nonfinancial firms may own and } \\
\text { control banks. }\end{array}$ & $\begin{array}{l}\text { OCC and WBG } 2.3 \text { (higher values, more restrictive) } \\
\text { Unrestricted = } 1=\text { a nonfinancial firm may own } 100 \\
\text { percent of the equity in a bank; Permitted }=2= \\
\text { unrestricted with prior authorization or approval; } \\
\text { Restricted }=3=1 \text { limits are placed on ownership, such } \\
\text { as a maximum percentage of a bank's capital or } \\
\text { shares; and Prohibited }=4=\text { no equity investment in } \\
\text { a bank. }\end{array}$ & $\begin{array}{l}2.3 \text { What is the level of regulatory restrictiveness of ownership by } \\
\text { nonfinancial firms of banks? }\end{array}$ \\
\hline \multicolumn{4}{|l|}{ 3. Competition Regulatory Variables } \\
\hline (a) Limitations on Foreign Bank Entry/Ownership & $\begin{array}{l}\text { Whether foreign banks may own domestic banks and } \\
\text { whether foreign banks may enter a country's banking } \\
\text { industry. }\end{array}$ & $\begin{array}{l}\mathrm{OCC} \\
\text { Yes }=1 ; \text { No }=0\end{array}$ & \\
\hline (b) Entry into Banking Requirements & $\begin{array}{l}\text { Whether various types of legal submissions are } \\
\text { required to obtain a banking license. }\end{array}$ & $\begin{array}{l}\text { WBG } 1.8 .1-1.8 .8 \\
\text { Yes }=1 ; \mathrm{No}=0 \\
\text { Higher values indicating greater stringency. }\end{array}$ & $\begin{array}{l}\text { 1.8 Which of the following are legally required to be submitted } \\
\text { before issuance of the banking license? } \\
\text { 1.8.1 Draft by-laws? Yes / No } \\
\text { 1.8.2 Intended organization chart? Yes / No } \\
\text { 1.8.3 Financial projections for first three years? Yes / No } \\
\text { 1.8.4 Financial information on main potential shareholders? Yes / } \\
\text { No } \\
\text { 1.8.5 Background/experience of future directors? Yes / No } \\
\text { 1.8.6 Background/experience of future managers? Yes / No } \\
\text { 1.8.7 Sources of funds to be disbursed in the capitalization of new } \\
\text { banks? Yes / No } \\
\text { 1.8.8 Market differentiation intended for the new bank? Yes / No }\end{array}$ \\
\hline (c) Fraction of Entry Applications Denied & $\begin{array}{l}\text { The degree to which applications to enter banking are } \\
\text { denied. }\end{array}$ & WBG $(1.9 .1+1.10 .1) /(1.9+1.10)$ (pure number) & $\begin{array}{l}1.9 \text { In the past five years, how many applications for commercial } \\
\text { banking licenses have been received from domestic entities? } \\
1.9 .1 \text { How many of those applications have been denied? } \\
1.10 \text { In the past five years, how many applications for commercial } \\
\text { banking licenses have been received from foreign entities? } \\
1.10 .1 \text { How many of those applications have been denied? }\end{array}$ \\
\hline (1) Domestic Denials & $\begin{array}{l}\text { The degree to which foreign applications to enter } \\
\text { banking are denied. }\end{array}$ & WBG 1.9.1 / 1.9 (pure number) & $\begin{array}{l}1.9 \text { In the past five years, how many applications for commercial } \\
\text { banking licenses have been received from domestic entities? } \\
1.9 .1 \text { How many of those applications have been denied? }\end{array}$ \\
\hline (2) Foreign Denials & $\begin{array}{l}\text { The degree to which domestic applications to enter } \\
\text { banking are denied. }\end{array}$ & WBG 1.10.1/1.10 (pure number) & $\begin{array}{l}\text { 1.10 In the past five years, how many applications for commercial } \\
\text { banking licenses have been received from foreign entities? } \\
1.10 .1 \text { How many of those applications have been denied? }\end{array}$ \\
\hline
\end{tabular}


Table 1

Information on Bank Regulatory, Supervisory and Deposit Insurance Variables

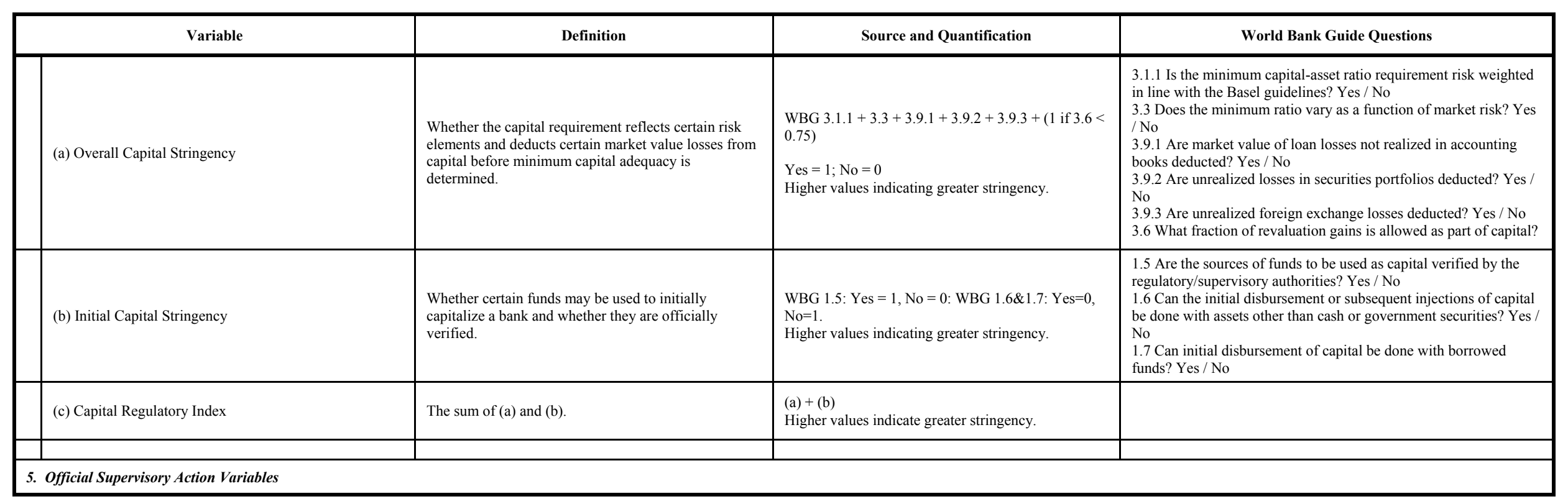


Table 1

Information on Bank Regulatory, Supervisory and Deposit Insurance Variables

\begin{tabular}{|c|c|c|c|}
\hline Variable & Definition & Source and Quantification & World Bank Guide Questions \\
\hline (a) Official Supervisory Power & $\begin{array}{l}\text { Whether the supervisory authorities have the authority } \\
\text { to take specific actions to prevent and correct } \\
\text { problems. }\end{array}$ & $x^{2}$ & $\begin{array}{l}\text { 5.5 Does the supervisory agency have the right to meet with } \\
\text { external auditors to discuss their report without the approval of the } \\
\text { bank? Yes / No } \\
\text { 5.6 Are auditors required by law to communicate directly to the } \\
\text { supervisory agency any presumed involvement of bank directors or } \\
\text { senior managers in elicit activities, fraud, or insider abuse? Yes / } \\
\text { No } \\
\text { 5.7 Can supervisors take legal action against external auditors for } \\
\text { negligence? Yes / No } \\
\text { 6.1 Can the supervisory authority force a bank to change its } \\
\text { internal organizational structure? Yes / No } \\
\text { 10.4 Are off-balance sheet items disclosed to supervisors? Yes / No } \\
\text { 11.2 Can the supervisory agency order the bank's directors or } \\
\text { management to constitute provisions to cover actual or potential } \\
\text { losses? Yes / No } \\
\text { 11.3 Can the supervisory agency suspend the directors' decision to } \\
\text { distribute: } \\
\text { 11.3.1 Dividends? Yes / No } \\
\text { 11.3.2 Bonuses? Yes / No } \\
\text { 11.3.3 Management fees? Yes / No } \\
\text { 1.6 Can the supervisory agency legally declare-such that this } \\
\text { declaration supersedes the rights of bank shareholders-that a bank } \\
\text { is insolvent? Yes / No } \\
\text { 11.7 Does the Banking Law give authority to the supervisory } \\
\text { agency to } \\
\text { intervene that is, suspend some or all ownership rights-a problem } \\
\text { bank? Yes / No } \\
\text { 11.9 Regarding bank restructuring and reorganization, can the } \\
\text { supervisory agency } \\
\text { or any other government agency do the following: ? Yes / No } \\
\text { 11.9.1 Supersede shareholder rights? Yes / No } \\
\text { 11.9.2 Remove and replace management? Yes / No } \\
\text { 11.9.3 Remove and replace directors? Yes / No }\end{array}$ \\
\hline (1) Prompt Corrective Power & $\begin{array}{l}\text { Whether the law establishes predetermined levels of } \\
\text { bank solvency deterioration that force automatic } \\
\text { actions, such as intervention. }\end{array}$ & $\begin{array}{l}\text { WBG } 11.8 *(11.1+11.2+11.3 .1+11.3 .2+11.3 .3 \\
+6.1) \\
\text { Yes }=1 ; \mathrm{No}=0 \\
\text { Principal component of the assigned values for the } \\
\text { items in parenthesis multiplied by } 1 \text { if there is a } \\
\text { legally pre-determined level of solvency } \\
\text { deterioration forcing automatic actions and by } 0 \text { if } \\
\text { not. }\end{array}$ & $\begin{array}{l}\text { 11.8 Does the Law establish pre-determined levels of solvency } \\
\text { deterioration which forces automatic actions (like intervention)? } \\
\text { Yes / No } \\
\text { 11.1 Are there any mechanisms of cease and desist-type orders, } \\
\text { whose infraction leads to the automatic imposition of civil and } \\
\text { penal sanctions on the bank's directors and managers? Yes / No } \\
\text { 11.2 Can the supervisory agency order the bank's directors or } \\
\text { management to constitute provisions to cover actual or potential } \\
\text { losses? Yes / No } \\
\text { 11.3 Can the supervisory agency suspend the directors' decision to } \\
\text { distribute: } \\
\text { 11.3.1 Dividends? Yes / No } \\
\text { 11.3.2 Bonuses? Yes / No } \\
\text { 11.3.3 Management fees? Yes / No } \\
\text { 6.1 Can the supervisory authority force a bank to change its } \\
\text { internal organizational structure? Yes / No }\end{array}$ \\
\hline
\end{tabular}


Table 1

Information on Bank Regulatory, Supervisory and Deposit Insurance Variables

\begin{tabular}{|c|c|c|c|}
\hline Variable & Definition & Source and Quantification & World Bank Guide Questions \\
\hline (2) Restructuring Power & $\begin{array}{l}\text { Whether the supervisory authorities have the power to } \\
\text { restructure and reorganize a troubled bank. }\end{array}$ & $\begin{array}{l}\text { WBG } 11.9 .1+11.9 .2+11.9 .3 \\
\text { Yes }=1 ; \text { No }=0 \\
\text { Higher values indicate greater restructuring power }\end{array}$ & $\begin{array}{l}\text { 11.9 Regarding bank restructuring and reorganization, can the } \\
\text { supervisory agency or any other government agency do the } \\
\text { following: } \\
\text { 11.9.1 Supersede shareholder rights? Yes / No } \\
\text { 11.9.2 Remove and replace management? Yes / No } \\
\text { 11.9.3 Remove and replace directors? Yes / No }\end{array}$ \\
\hline (3) Declaring Insolvency Power & $\begin{array}{l}\text { Whether the supervisory authorities have the power to } \\
\text { declare a deeply troubled bank insolvent. }\end{array}$ & $\begin{array}{l}\text { WBG } 11.6+11.7 \\
\text { Yes }=1 ; \text { No }=0 \\
\text { Higher values indicating greater power. }\end{array}$ & $\begin{array}{l}\text { 11.6 Can the supervisory agency legally declare-such that this } \\
\text { declaration supersedes the rights of bank shareholders-that a bank } \\
\text { is insolvent? Yes / No } \\
11.7 \text { Does the Banking Law give authority to the supervisory } \\
\text { agency to intervene-that is, suspend some or all ownership rights-a } \\
\text { problem bank? Yes / No }\end{array}$ \\
\hline (b) Supervisory Forbearance Discretion & $\begin{array}{l}\text { Whether the supervisory authorities may engage in } \\
\text { forbearance when confronted with violations of laws } \\
\text { and regulations or other imprudent behavior. }\end{array}$ & $\begin{array}{l}\text { WBG } 11.9 .4+(12.10-1) *(-1)+(11.8-1) *(-1)+ \\
(12.11-1) *(-1) \\
\text { Yes }=1 ; \mathrm{No}=0 \\
\text { Sum of these assigned values such that higher values } \\
\text { indicate greater discretion. }\end{array}$ & $\begin{array}{l}\text { 11.9.4 Can the supervisory agency or any other government agency } \\
\text { forbear certain prudential regulations? Yes / No } \\
\text { 11.8 Does the Law establish pre-determined levels of solvency } \\
\text { deterioration which forces automatic actions (like intervention)? } \\
\text { Yes / No } \\
\text { 12.10 If an infraction of any prudential regulation is found by a } \\
\text { supervisor, must it be reported? Yes / No } \\
\text { 12.11 Are there mandatory actions in these cases? Yes / No }\end{array}$ \\
\hline (c) Loan Classification Stringency & $\begin{array}{l}\text { The classification of loans in arrears as sub-standard, } \\
\text { doubtful and loss. }\end{array}$ & $\begin{array}{l}\text { WBG 9.2.1 - } 9.2 .3 \text { (days) } \\
\text { If there is a loan classification system, the actual } \\
\text { minimum number of days beyond which a loan in } \\
\text { arrears must be classified as sub-standard, then } \\
\text { doubtful, and finally loss are summed. Higher } \\
\text { values indicate less stringency. }\end{array}$ & $\begin{array}{l}\text { 9.2 Classification of loans in arrears based on their quality: after } \\
\text { how many days is a loan in arrears classified as: } \\
\text { 9.2.1 Sub-standard? } \\
\text { 9.2.2 Doubtful? } \\
\text { 9.2.3 Loss? }\end{array}$ \\
\hline (d) Provisioning Stringency & $\begin{array}{l}\text { The minimum required provisions as loans become } \\
\text { sub-standard, doubtful and loss. }\end{array}$ & $\begin{array}{l}\text { WBG 9.3.1 - } 9.3 .3 \text { (percent) } \\
\text { The sum of the minimum required provisioning } \\
\text { percentages when a loan is successively classified as } \\
\text { substandard, doubtful, and loss. If a range is } \\
\text { provided, the minimum percentage is used. Higher } \\
\text { values indicate greater stringency. }\end{array}$ & $\begin{array}{l}\text { 9.3 What are the minimum required provision as loans become: } \\
\text { 9.3.1 Sub-standard? } \\
\text { 9.3.2 Doubtful? } \\
\text { 9.3.3 Loss? }\end{array}$ \\
\hline (e) Diversification Index & $\begin{array}{l}\text { Whether there are explicit, verifiable, quantifiable } \\
\text { guidelines for asset diversification, and banks are } \\
\text { allowed to make loans abroad. }\end{array}$ & $\begin{array}{l}\text { WBG } 7.1+(7.2-1) *(-1) \\
\text { Yes }=1 ; \text { No }=0 \\
\text { Sum of these assigned values, with higher values } \\
\text { indicating more diversification. }\end{array}$ & $\begin{array}{l}\text { 7.1 Are there explicit, verifiable, and quantifiable guidelines } \\
\text { regarding asset diversification? Yes / No } \\
7.2 \text { Are banks prohibited from making loans abroad? Yes / No }\end{array}$ \\
\hline \multicolumn{4}{|l|}{ 6. Official Supervisory Resource Variables } \\
\hline (a) Supervisor Tenure & The average tenure of a professional bank supervisor. & WBG 12.9.1 (years) & $\begin{array}{l}12.8 \text { What is the average tenure of current supervisors (i.e., what is } \\
\text { the average number of years current supervisors have been } \\
\text { supervisors)? }\end{array}$ \\
\hline
\end{tabular}


Table 1

Information on Bank Regulatory, Supervisory and Deposit Insurance Variables

\begin{tabular}{|c|c|c|c|}
\hline Variable & Definition & Source and Quantification & World Bank Guide Questions \\
\hline (b) Independence of Supervisory Authority-Political & $\begin{array}{l}\text { The degree to which the supervisory authority is } \\
\text { independent within the government from political } \\
\text { influence. }\end{array}$ & $\begin{array}{l}\text { WBG } 12.2,12.2 .1 \text { and } 12.2 .2 \\
1=\text { low independence; } 2=\text { medium independence; } 3 \\
=\text { high independence }\end{array}$ & $\begin{array}{l}\text { 12.2 To whom are the supervisory bodies responsible or } \\
\text { accountable? } \\
\text { 12.2.1 How is the head of the supervisory agency (and other } \\
\text { directors) appointed? } \\
\text { 12.2.2 How is the head of the supervisory agency (and other } \\
\text { directors) removed? }\end{array}$ \\
\hline (c) Independence of Supervisory Authority - Banks & $\begin{array}{l}\text { The degree to which the supervisory authority is } \\
\text { protected by the legal system from the banking } \\
\text { industry. }\end{array}$ & $\begin{array}{l}\text { WBG } 12.14 \\
\text { Yes }=0 ; \mathrm{No}=1\end{array}$ & 12.14 Are supervisors legally liable for their actions? \\
\hline (d) Independence of Supervisory Authority - Overall & $\begin{array}{l}\text { The degree to which the supervisory authority is } \\
\text { independent from the government and legally } \\
\text { protected from the banking industry. }\end{array}$ & $\begin{array}{l}\text { WBG }(b)+(c) \\
\text { Higher values signify greater independence }\end{array}$ & \\
\hline (e) Multiple Supervisors & $\begin{array}{l}\text { This variable indicates whether there is a single } \\
\text { official regulatory of banks, or whether multiple } \\
\text { supervisor share responsibility for supervising the } \\
\text { nation's banks. }\end{array}$ & $\begin{array}{l}\text { This variable is assigned a value of } 1 \text { if there is more } \\
\text { than one supervisor and } 0 \text { otherwise. }\end{array}$ & $\begin{array}{l}\text { 12.1 What body/agency supervises banks? } \\
\text { 12.1.1 Is there more than one supervisory body? } \\
\text { 12.2 To whom are the supervisory bodies responsible or } \\
\text { accountable? } \\
\text { 12.2.1 How is the head of the supervisory agency (and other } \\
\text { directors) appointed? } \\
\text { 12.2.2 How is the head of the supervisory agency (and other } \\
\text { directors) removed? }\end{array}$ \\
\hline \multicolumn{4}{|l|}{ 7. Private Monitoring Variables } \\
\hline (a) Certified Audit Required & $\begin{array}{l}\text { Whether there is a compulsory external audit by a } \\
\text { licensed or certified auditor. }\end{array}$ & WBG $5.1 * 5.3($ Yes $=1 ;$ No $=0)$ & $\begin{array}{l}5.1 \text { Is an external audit a compulsory obligation for banks? Yes / } \\
\text { No } \\
5.3 \text { Are auditors licensed or certified? Yes / No }\end{array}$ \\
\hline $\begin{array}{l}\text { (b) Percent of } 10 \text { Biggest Banks Rated by International } \\
\text { Rating Agencies }\end{array}$ & $\begin{array}{l}\text { The percentage of the top ten banks that are rated by } \\
\text { international credit rating agencies. }\end{array}$ & WBG 10.7.1 (percent) & $\begin{array}{l}\text { 10.7.1 What percent of the top ten banks are rated by international } \\
\text { credit rating agencies (e.g., Moody's, Standard and Poor)? }\end{array}$ \\
\hline (c) No Explicit Deposit Insurance Scheme & $\begin{array}{l}\text { Whether there is an explicit deposit insurance scheme } \\
\text { and, if not, whether depositors were fully compensated } \\
\text { the last time a bank failed. }\end{array}$ & $\begin{array}{l}\text { WBG } 1 \text { if } 8.1=0 \text { and } 8.4=0 ; 0 \text { otherwise } \\
\text { Yes }=1 ; \text { No }=0 \\
\text { Higher values indicate more private supervision }\end{array}$ & $\begin{array}{l}\text { 8.1 Is there an explicit deposit insurance protection system? Yes / } \\
\text { No } \\
8.4 \text { Were depositors wholly compensated (to the extent of legal } \\
\text { protection) the last time a bank failed? Yes / No }\end{array}$ \\
\hline (d) Bank Accounting & $\begin{array}{l}\text { Whether the income statement includes accrued or } \\
\text { unpaid interest or principal on nonperforming loans } \\
\text { and whether banks are required to produce } \\
\text { consolidated financial statements. }\end{array}$ & $\begin{array}{l}\text { WBG }(10.1 .1-1)^{*}(-1)+10.3+10.6 \\
\text { Yes }=1 ; \text { No }=0 \\
\text { Sum of assigned values, with higher values } \\
\text { indicating more informative bank accounts. }\end{array}$ & $\begin{array}{l}\text { 10.1.1 Does accrued, though unpaid interest/principal enter the } \\
\text { income statement while the loan is still non-performing? } \\
\text { 10.3 Are financial institutions required to produce consolidated } \\
\text { accounts covering all bank and any non-bank financial } \\
\text { subsidiaries? } 10.6 \text { Are bank directors legally liable if information } \\
\text { disclosed is erroneous or misleading? }\end{array}$ \\
\hline
\end{tabular}


Table 1

Information on Bank Regulatory, Supervisory and Deposit Insurance Variables

\begin{tabular}{|c|c|c|c|}
\hline Variable & Definition & Source and Quantification & World Bank Guide Questions \\
\hline (e) Private Monitoring Index & $\begin{array}{l}\text { Whether (a) occurs, (b) equals } 100 \% \text {, (c) occurs, (d) } \\
\text { occurs, off-balance sheet items are disclosed to the } \\
\text { public, banks must disclose risk management } \\
\text { procedures to the public, and subordinated debt is } \\
\text { allowable (required) as a part of regulatory capital. }\end{array}$ & $\begin{array}{l}\text { WBG: (a) }+[1 \text { if (b) equals } 100 \% ; 0 \text { otherwise }]+ \\
\text { (c) }+(d)+10.4 .1+10.5+3.5 \\
\text { Yes }=1 ; \text { No }=0 \\
\text { Higher values indicating more private supervision. }\end{array}$ & $\begin{array}{l}\text { 10.4.1 Are off-balance sheet items disclosed to the public? Yes / } \\
\text { No } \\
10.5 \text { Must banks disclose their risk management procedures to the } \\
\text { public? Yes / No } \\
3.5 \text { Is subordinated debt allowable (required) as part of capital? Yes } \\
\text { / No }\end{array}$ \\
\hline \multicolumn{4}{|l|}{ 8. Deposit Insurance Scheme Variables } \\
\hline (a) Deposit Insurer Power & $\begin{array}{l}\text { Whether the deposit insurance authority has the } \\
\text { authority to make the decision to intervene in a bank, } \\
\text { take legal action against bank directors or officials, and } \\
\text { has ever taken any legal action against bank directors } \\
\text { or officers. }\end{array}$ & $\begin{array}{l}\text { WBG } 8.1 .5+8.6+8.7 \\
\text { Yes }=1 ; \text { No }=0 \\
\text { Sum of assigned values, with higher values } \\
\text { indicating more power. }\end{array}$ & $\begin{array}{l}\text { 8.1.5 Does the deposit insurance authority make the decision to } \\
\text { intervene a bank? Yes / No } \\
8.6 \text { Can the deposit insurance agency/fund take legal action against } \\
\text { bank directors or other bank officials? Yes / No } \\
8.7 \text { Has the deposit insurance agency/fund ever taken legal action } \\
\text { against bank directors or other bank officials? Yes / No }\end{array}$ \\
\hline (b) Deposit Insurance Funds-to-Total Bank Assets & $\begin{array}{l}\text { The size of the deposit insurance fund relative to total } \\
\text { bank assets. }\end{array}$ & WBG 8.1.2 (pure number) & 8.1.2 What is the ratio of accumulated funds to total bank assets? \\
\hline (c) Moral Hazard Index & The degree to which moral hazard exists. & $\begin{array}{l}\text { Demirguc-Kunt and Detragiache (2002) } \\
\text { Higher values indicate more moral hazard. }\end{array}$ & \\
\hline \multicolumn{4}{|l|}{ 9. Market Structure Indicators } \\
\hline (a) Bank Concentration & $\begin{array}{l}\text { The degree of concentration of deposits in the } 5 \text { largest } \\
\text { banks. }\end{array}$ & WBG 2.6 (pure number) & $\begin{array}{l}\text { 2.6 Of deposit-taking institutions in your country, what fraction of } \\
\text { deposits is held by the five (5) largest banks? }\end{array}$ \\
\hline (b) Foreign-Owned Banks & $\begin{array}{l}\text { The extent to which the banking system's assets are } \\
\text { foreign owned. }\end{array}$ & WBG 3.8 (percent) & $\begin{array}{l}\text { 3.8 What fraction of the banking system's assets is in banks that are } \\
50 \% \text { or more foreign owned? }\end{array}$ \\
\hline (c) Government-Owned Banks & $\begin{array}{l}\text { The extent to which the banking system's assets are } \\
\text { government owned. }\end{array}$ & WBG 3.7 (percent) & $\begin{array}{l}\text { 3.7 What fraction of the banking system's assets is in banks that are } \\
50 \% \text { or more government owned? }\end{array}$ \\
\hline
\end{tabular}

Note: WBG denotes World Bank Guide, which is available at www.worldbank.org/research/interest/intrstweb.htm 
Table 2

\section{Correlations Among Selected Variables}

\begin{tabular}{|c|c|c|c|c|c|c|c|c|c|c|c|c|c|c|}
\hline & $\begin{array}{l}\text { Entry into } \\
\text { Banking } \\
\text { Requirements } \\
\text { Index }\end{array}$ & $\begin{array}{c}\text { Entry } \\
\text { Applications } \\
\text { Denied }\end{array}$ & $\begin{array}{l}\text { Capital } \\
\text { Regulatory } \\
\text { Index }\end{array}$ & $\begin{array}{l}\text { Restrictio } \\
\text { ns on } \\
\text { Bank } \\
\text { Activities } \\
\text { Index }\end{array}$ & $\begin{array}{l}\text { Private } \\
\text { Monitoring } \\
\text { Index }\end{array}$ & $\begin{array}{c}\text { Moral } \\
\text { Hazard } \\
\text { Index }\end{array}$ & $\begin{array}{c}\text { Official } \\
\text { Supervisory } \\
\text { Power Index }\end{array}$ & $\begin{array}{l}\text { Prompt } \\
\text { Corrective } \\
\text { Power } \\
\text { Index }\end{array}$ & $\begin{array}{l}\text { No } \\
\text { Foreign } \\
\text { Loans }\end{array}$ & $\begin{array}{c}\text { Government- } \\
\text { Owned } \\
\text { Banks }\end{array}$ & $\begin{array}{c}\text { Bank } \\
\text { Development }\end{array}$ & $\begin{array}{c}\text { Net } \\
\text { Interest } \\
\text { Margin }\end{array}$ & $\begin{array}{l}\text { Overhead } \\
\text { Costs }\end{array}$ & $\begin{array}{c}\text { Major } \\
\text { Banking } \\
\text { Crisis }\end{array}$ \\
\hline Entry Applications Denied & $\begin{array}{l}-0.02 \\
(0.904)\end{array}$ & 1 & & & & & & & & & & & & \\
\hline Capital Regulatory Index & $\begin{array}{c}0.02 \\
(0.853)\end{array}$ & $\begin{array}{l}-0.47 * * \\
(0.000)\end{array}$ & 1 & & & & & & & & & & & \\
\hline $\begin{array}{l}\text { Restrictions on Bank Activities } \\
\text { Index }\end{array}$ & $\begin{array}{c}0.04 \\
(0.757)\end{array}$ & $\begin{array}{l}0.36^{* *} \\
(0.003)\end{array}$ & $\begin{array}{l}-0.20^{*} \\
(0.072)\end{array}$ & 1 & & & & & & & & & & \\
\hline Private Monitoring Index & $\begin{array}{c}-0.16 \\
(0.201)\end{array}$ & $\begin{array}{l}-0.47 * * \\
(0.000)\end{array}$ & $\begin{array}{c}0.23^{*} \\
(0.060)\end{array}$ & $\begin{array}{l}-0.35^{* *} \\
(0.004)\end{array}$ & 1 & & & & & & & & & \\
\hline Moral Hazard Index & $\begin{array}{l}-0.21 \\
(0.152)\end{array}$ & $\begin{array}{c}-0.19 \\
(0.247)\end{array}$ & $\begin{array}{l}0.29 * * \\
(0.046)\end{array}$ & $\begin{array}{l}-0.23 \\
(0.110)\end{array}$ & $\begin{array}{c}0.18 \\
(0.230)\end{array}$ & 1 & & & & & & & & \\
\hline $\begin{array}{l}\text { Official Supervisory Power } \\
\text { Index }\end{array}$ & $\begin{array}{c}0.01 \\
(0.937)\end{array}$ & $\begin{array}{c}0.08 \\
(0.620)\end{array}$ & $\begin{array}{c}-0.19 \\
(0.215)\end{array}$ & $\begin{array}{l}-0.05 \\
(0.720)\end{array}$ & $\begin{array}{c}0.07 \\
(0.685)\end{array}$ & $\begin{array}{c}0.18 \\
(0.375)\end{array}$ & 1 & & & & & & & \\
\hline Prompt Corrective Power Index & $\begin{array}{c}0.10 \\
(0.388)\end{array}$ & $\begin{array}{c}0.14 \\
(0.284)\end{array}$ & $\begin{array}{l}-0.04 \\
(0.700)\end{array}$ & $\begin{array}{c}0.13 \\
(0.269)\end{array}$ & $\begin{array}{l}-0.21^{*} \\
(0.094)\end{array}$ & $\begin{array}{l}0.23 \\
(0.122)\end{array}$ & $\begin{array}{l}0.48^{* *} \\
(0.001)\end{array}$ & 1 & & & & & & \\
\hline No Foreign Loans & $\begin{array}{c}0.03 \\
(0.820)\end{array}$ & $\begin{array}{l}0.26^{* *} \\
(0.034)\end{array}$ & $\begin{array}{l}-0.02 \\
(0.840)\end{array}$ & $\begin{array}{l}0.23^{* *} \\
(0.040)\end{array}$ & $\begin{array}{l}-0.21^{*} \\
(0.081)\end{array}$ & $\begin{array}{l}-0.17 \\
(0.243)\end{array}$ & $\begin{array}{c}0.03 \\
(0.847)\end{array}$ & $\begin{array}{c}0.09 \\
(0.408)\end{array}$ & 1 & & & & & \\
\hline Government-Owned Banks & $\begin{array}{c}-0.13 \\
(0.273)\end{array}$ & $\begin{array}{l}0.39^{* *} \\
(0.003)\end{array}$ & $\begin{array}{l}-0.15 \\
(0.209)\end{array}$ & $\begin{array}{l}0.33^{* *} \\
(0.005)\end{array}$ & $\begin{array}{l}-0.36^{* *} \\
(0.005)\end{array}$ & $\begin{array}{l}-0.06 \\
(0.700)\end{array}$ & $\begin{array}{l}-0.06 \\
(0.677)\end{array}$ & $\begin{array}{l}-0.09 \\
(0.431)\end{array}$ & $\begin{array}{l}0.27^{* *} \\
(0.021)\end{array}$ & 1 & & & & \\
\hline Bank Development & $\begin{array}{c}-0.11 \\
(0.325)\end{array}$ & $\begin{array}{l}-0.20 \\
(0.122)\end{array}$ & $\begin{array}{c}0.21 * \\
(0.070)\end{array}$ & $\begin{array}{l}-0.39 * * \\
(0.000)\end{array}$ & $\begin{array}{l}0.48^{* *} \\
(0.000)\end{array}$ & $\begin{array}{c}0.07 \\
(0.627)\end{array}$ & $\begin{array}{c}-0.09 \\
(0.546)\end{array}$ & $\begin{array}{l}-0.24 * * \\
(0.040)\end{array}$ & $\begin{array}{l}-0.08 \\
(0.513)\end{array}$ & $\begin{array}{l}-0.29 * * \\
(0.014)\end{array}$ & 1 & & & \\
\hline Net Interest Margin & $\begin{array}{l}0.18 \\
(0.120)\end{array}$ & $\begin{array}{c}0.11 \\
(0.418)\end{array}$ & $\begin{array}{l}-0.18 \\
(0.125)\end{array}$ & $\begin{array}{l}0.28^{* *} \\
(0.014)\end{array}$ & $\begin{array}{l}-0.37 * * \\
(0.002)\end{array}$ & $\begin{array}{l}-0.03 \\
(0.852)\end{array}$ & $\begin{array}{c}0.12 \\
(0.459)\end{array}$ & $\begin{array}{c}0.14 \\
(0.249)\end{array}$ & $\begin{array}{c}0.19^{*} \\
(0.095)\end{array}$ & $\begin{array}{l}0.26 * * \\
(0.037)\end{array}$ & $\begin{array}{l}-0.57^{* *} \\
(0.000)\end{array}$ & 1 & & \\
\hline Overhead Costs & $\begin{array}{l}0.23 * * \\
(0.041)\end{array}$ & $\begin{array}{l}-0.02 \\
(0.857)\end{array}$ & $\begin{array}{l}-0.03 \\
(0.823)\end{array}$ & $\begin{array}{c}0.04 \\
(0.715)\end{array}$ & $\begin{array}{l}-0.25^{* *} \\
(0.044)\end{array}$ & $\begin{array}{c}0.12 \\
(0.415)\end{array}$ & $\begin{array}{c}0.11 \\
(0.496)\end{array}$ & $\begin{array}{c}0.09 \\
(0.453)\end{array}$ & $\begin{array}{c}-0.02 \\
(0.836)\end{array}$ & $\begin{array}{l}0.30^{* *} \\
(0.014)\end{array}$ & $\begin{array}{l}-0.58^{* *} \\
(0.000)\end{array}$ & $\begin{array}{l}0.76^{* *} \\
(0.000)\end{array}$ & 1 & \\
\hline Major Banking Crisis & $\begin{array}{l}-0.17 \\
(0.123)\end{array}$ & $\begin{array}{c}0.14 \\
(0.278)\end{array}$ & $\begin{array}{c}-0.11 \\
(0.326)\end{array}$ & $\begin{array}{c}0.18 \\
(0.116)\end{array}$ & $\begin{array}{c}-0.07 \\
(0.569)\end{array}$ & $\begin{array}{l}0.43 * * \\
(0.002)\end{array}$ & $\begin{array}{c}0.13 \\
(0.398)\end{array}$ & $\begin{array}{c}0.15 \\
(0.197)\end{array}$ & $\begin{array}{l}0.17 \\
(0.131)\end{array}$ & $\begin{array}{l}0.26 * * \\
(0.027)\end{array}$ & $\begin{array}{l}-0.21^{*} \\
(0.061)\end{array}$ & $\begin{array}{c}0.13 \\
(0.275)\end{array}$ & $\begin{array}{c}0.14 \\
(0.237)\end{array}$ & 1 \\
\hline Government Integrity & $\begin{array}{c}-0.09 \\
(0.509)\end{array}$ & $\begin{array}{l}-0.48^{* *} \\
(0.001)\end{array}$ & $\begin{array}{c}0.31^{* *} \\
(0.018)\end{array}$ & $\begin{array}{c}-0.55^{* *} \\
(0.000)\end{array}$ & $\begin{array}{c}0.62^{* *} \\
(0.000)\end{array}$ & $\begin{array}{c}0.11 \\
(0.455)\end{array}$ & $\begin{array}{c}-0.26 \\
(0.154)\end{array}$ & $\begin{array}{c}-0.24 * \\
(0.067)\end{array}$ & $\begin{array}{c}-0.37 * * \\
(0.005)\end{array}$ & $\begin{array}{c}-0.42^{* *} \\
(0.002)\end{array}$ & $\begin{array}{c}0.54^{* *} \\
(0.000)\end{array}$ & $\begin{array}{c}-0.44^{* *} \\
(0.001)\end{array}$ & $\begin{array}{c}-0.42^{* *} \\
(0.002)\end{array}$ & $\begin{array}{c}-0.41^{* *} \\
(0.002)\end{array}$ \\
\hline
\end{tabular}

Note: P-values are in parentheses. ** indicates significant at the 0.05 level, while * indicates significant at the 0.10 level. And the following indices are principal component versions: Entry into Banking Requirements, Capital Regulatory Index, Restrictions on Bank Activities, Private Monitoring Index, and Official Supervisory Power. 
Table 3

Bank Development and Performance Regressions

\begin{tabular}{|c|c|c|c|c|c|c|c|c|c|}
\hline Dependent Variable & Constant $t^{1}$ & $\begin{array}{l}\text { Capital } \\
\text { Regulatory } \\
\text { Index }\end{array}$ & $\begin{array}{l}\text { Private } \\
\text { Monitoring } \\
\text { Index }\end{array}$ & $\begin{array}{c}\text { Official } \\
\text { Supervisory } \\
\text { Power } \\
\text { Index }\end{array}$ & $\begin{array}{c}\text { Entry into } \\
\text { Banking } \\
\text { Requirements } \\
\text { Index }\end{array}$ & $\begin{array}{c}\text { Restrictions } \\
\text { on Bank } \\
\text { Activities } \\
\text { Index }\end{array}$ & $\begin{array}{c}\text { Government- } \\
\text { Owned } \\
\text { Banks }\end{array}$ & $\mathrm{N}$ & $\begin{array}{c}\text { R- } \\
\text { Square }\end{array}$ \\
\hline Bank Development & $\begin{array}{c}0.189 * * \\
(0.004)\end{array}$ & $\begin{array}{l}-0.011 \\
(0.725)\end{array}$ & $\begin{array}{c}0.089 * * \\
(0.003)\end{array}$ & $\begin{array}{l}-0.042 \\
(0.172)\end{array}$ & $\begin{array}{c}0.002 \\
(0.939)\end{array}$ & $\begin{array}{c}-0.118 * * \\
(0.001)\end{array}$ & & 75 & 0.597 \\
\hline Net Interest Margin & $\begin{array}{c}0.042 * * \\
(0.000)\end{array}$ & $\begin{array}{l}-0.003 \\
(0.373)\end{array}$ & $\begin{array}{c}-0.010^{* *} \\
(0.012)\end{array}$ & $\begin{array}{c}0.000 \\
(0.870)\end{array}$ & $\begin{array}{c}0.003 \\
(0.190)\end{array}$ & $\begin{array}{c}0.004 \\
(0.241)\end{array}$ & & 75 & 0.264 \\
\hline Overhead Costs & $\begin{array}{c}0.032 * * \\
(0.000)\end{array}$ & $\begin{array}{c}0.001 \\
(0.789)\end{array}$ & $\begin{array}{l}-0.006^{*} \\
(0.077)\end{array}$ & $\begin{array}{c}0.000 \\
(0.965)\end{array}$ & $\begin{array}{l}0.003 * * \\
(0.042)\end{array}$ & $\begin{array}{l}-0.001 \\
(0.731)\end{array}$ & & 75 & 0.201 \\
\hline Nonperforming Loans & $\begin{array}{l}0.074 * \\
(0.063)\end{array}$ & $\begin{array}{l}-0.035^{*} \\
(0.058)\end{array}$ & $\begin{array}{c}-0.042 * * \\
(0.007)\end{array}$ & $\begin{array}{c}0.004 \\
(0.799)\end{array}$ & $\begin{array}{c}0.006 \\
(0.586)\end{array}$ & $\begin{array}{l}-0.011 \\
(0.567) \\
\end{array}$ & & 68 & 0.247 \\
\hline
\end{tabular}

\begin{tabular}{|c|c|c|c|c|c|c|c|c|c|}
\hline Dependent Variable & Constant $^{1}$ & $\begin{array}{l}\text { Capital } \\
\text { Regulatory } \\
\text { Index }\end{array}$ & $\begin{array}{l}\text { Private } \\
\text { Monitoring } \\
\text { Index }\end{array}$ & $\begin{array}{c}\text { Official } \\
\text { Supervisory } \\
\text { Power } \\
\text { Index }\end{array}$ & $\begin{array}{l}\text { Entry into } \\
\text { Banking } \\
\text { Requirements } \\
\text { Index }\end{array}$ & $\begin{array}{l}\text { Restrictions } \\
\text { on Bank } \\
\text { Activities } \\
\text { Index }\end{array}$ & $\begin{array}{c}\text { Government- } \\
\text { Owned } \\
\text { Banks }\end{array}$ & $\mathrm{N}$ & $\begin{array}{c}\mathrm{R}- \\
\text { Square }\end{array}$ \\
\hline Bank Development & $\begin{array}{c}0.232 * * \\
(0.000)\end{array}$ & $\begin{array}{l}-0.028 \\
(0.428)\end{array}$ & $\begin{array}{c}0.071^{* *} \\
(0.025)\end{array}$ & $\begin{array}{l}-0.029 \\
(0.322)\end{array}$ & $\begin{array}{l}-0.002 \\
(0.926)\end{array}$ & $\begin{array}{c}-0.119^{* *} \\
(0.002)\end{array}$ & $\begin{array}{l}-0.169 \\
(0.154)\end{array}$ & 68 & 0.623 \\
\hline Net Interest Margin & $\begin{array}{c}0.041 * * \\
(0.000)\end{array}$ & $\begin{array}{l}-0.002 \\
(0.660)\end{array}$ & $\begin{array}{c}-0.009^{* *} \\
(0.045)\end{array}$ & $\begin{array}{l}-0.001 \\
(0.713)\end{array}$ & $\begin{array}{c}0.003 \\
(0.156)\end{array}$ & $\begin{array}{c}0.006^{* *} \\
(0.075)\end{array}$ & $\begin{array}{c}0.006 \\
(0.760)\end{array}$ & 66 & 0.310 \\
\hline Overhead Costs & $\begin{array}{c}0.029 * * \\
(0.000)\end{array}$ & $\begin{array}{c}0.003 \\
(0.289)\end{array}$ & $\begin{array}{l}-0.004 \\
(0.282)\end{array}$ & $\begin{array}{c}0.000 \\
(0.889)\end{array}$ & $\begin{array}{c}0.004 * * \\
(0.036)\end{array}$ & $\begin{array}{c}0.000 \\
(0.984)\end{array}$ & $\begin{array}{c}0.022 \\
(0.209)\end{array}$ & 66 & 0.298 \\
\hline Nonperforming Loans & $\begin{array}{c}0.029 \\
(0.366)\end{array}$ & $\begin{array}{l}-0.034^{*} \\
(0.096)\end{array}$ & $\begin{array}{l}-0.028^{*} \\
(0.085)\end{array}$ & $\begin{array}{l}-0.005 \\
(0.713)\end{array}$ & $\begin{array}{c}0.011 \\
(0.235)\end{array}$ & $\begin{array}{l}-0.021 \\
(0.209)\end{array}$ & $\begin{array}{c}0.160 * * \\
(0.030)\end{array}$ & 63 & 0.318 \\
\hline
\end{tabular}

Notes: with P-values are in parentheses under the estimated coefficients, using heteroskedasticity-consistent standard errors from an OLS regression. ** indicates significant at the 0.05 level, while * indicates significant at the 0.10 level. Each row is a separate regression. Each regression also contains legal origin dummy variables (Common Law, French Civil Law, German Civil Law, and Socialist Law). And the following indices are principal component versions: Entry into Banking Requirements, Capital Regulatory Index, Restrictions on Bank Activities, Private Monitoring Index, and Official Supervisory Power. 
Table 4

Banking Crises Regressions

\begin{tabular}{|c|c|c|c|c|c|c|c|c|c|}
\hline & 1 & 2 & 3 & 4 & 5 & 6 & 7 & 8 & 9 \\
\hline 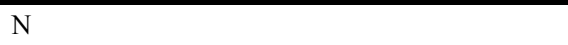 & 52 & 46 & 43 & 51 & 40 & 40 & 41 & 43 & 43 \\
\hline Constant & $\begin{array}{l}-0.566 \\
(0.323)\end{array}$ & $\begin{array}{l}-0.210 \\
(0.799)\end{array}$ & $\begin{array}{l}-0.314 \\
(0.626)\end{array}$ & $\begin{array}{c}0.764 \\
(0.505)\end{array}$ & $\begin{array}{c}-2.732 * * \\
(0.011)\end{array}$ & $\begin{array}{l}-1.409 \\
(0.345)\end{array}$ & $\begin{array}{c}1.760 \\
(0.450)\end{array}$ & $\begin{array}{l}-0.308 \\
(0.637)\end{array}$ & $\begin{array}{l}-0.094 \\
(0.905)\end{array}$ \\
\hline Restrictions on Bank Activities Index & $\begin{array}{l}0.631 * \\
(0.073)\end{array}$ & $\begin{array}{l}1.158^{* *} \\
(0.016)\end{array}$ & $\begin{array}{c}0.647 \\
(0.174)\end{array}$ & $\begin{array}{l}0.771 * \\
(0.083)\end{array}$ & $\begin{array}{l}1.709 * * \\
(0.034)\end{array}$ & $\begin{array}{l}1.880 * * \\
(0.043)\end{array}$ & $\begin{array}{c}0.735 \\
(0.265)\end{array}$ & $\begin{array}{c}0.656 \\
(0.168)\end{array}$ & $\begin{array}{c}0.627 \\
(0.193)\end{array}$ \\
\hline Entry into Banking Requirements Index & $\begin{array}{l}-0.183 \\
(0.495)\end{array}$ & $\begin{array}{l}-0.279 \\
(0.381)\end{array}$ & $\begin{array}{c}0.125 \\
(0.614)\end{array}$ & $\begin{array}{l}-0.309 \\
(0.350)\end{array}$ & $\begin{array}{l}-0.704 \\
(0.142)\end{array}$ & $\begin{array}{c}0.398 \\
(0.279)\end{array}$ & $\begin{array}{c}0.249 \\
(0.432)\end{array}$ & $\begin{array}{c}0.127 \\
(0.613)\end{array}$ & $\begin{array}{c}0.164 \\
(0.599)\end{array}$ \\
\hline Capital Regulatory Index & $\begin{array}{l}-0.264 \\
(0.471)\end{array}$ & $\begin{array}{l}-0.749 \\
(0.173)\end{array}$ & $\begin{array}{l}-1.035^{*} \\
(0.069)\end{array}$ & $\begin{array}{l}-0.155 \\
(0.735)\end{array}$ & $\begin{array}{l}-0.107 \\
(0.885)\end{array}$ & $\begin{array}{l}-1.268 \\
(0.340)\end{array}$ & $\begin{array}{c}-1.075^{* *} \\
(0.033)\end{array}$ & $\begin{array}{l}-1.026^{*} \\
(0.081)\end{array}$ & $\begin{array}{l}-1.201 * \\
(0.054)\end{array}$ \\
\hline Private Monitoring Index & $\begin{array}{c}0.391 \\
(0.431)\end{array}$ & $\begin{array}{l}-0.016 \\
(0.980)\end{array}$ & & $\begin{array}{c}0.169 \\
(0.709)\end{array}$ & $\begin{array}{c}1.168 \\
(0.121)\end{array}$ & & & & \\
\hline Official Supervisory Power Index & $\begin{array}{l}-0.270 \\
(0.388)\end{array}$ & $\begin{array}{l}-0.224 \\
(0.492)\end{array}$ & $\begin{array}{l}-0.243 \\
(0.566)\end{array}$ & & $\begin{array}{l}-0.655 \\
(0.316)\end{array}$ & $\begin{array}{l}-1.190 \\
(0.224)\end{array}$ & $\begin{array}{c}-0.222 \\
(0.598)\end{array}$ & $\begin{array}{l}-0.246 \\
(0.567)\end{array}$ & $\begin{array}{l}-0.241 \\
(0.582)\end{array}$ \\
\hline Government-Owned Banks & $\begin{array}{c}2.312 \\
(0.195)\end{array}$ & $\begin{array}{l}5.269^{*} \\
(0.087)\end{array}$ & $\begin{array}{l}2.846 \\
(0.185)\end{array}$ & $\begin{array}{c}1.537 \\
(0.496)\end{array}$ & $\begin{array}{c}3.414 \\
(0.256)\end{array}$ & $\begin{array}{c}9.477 \\
(0.114)\end{array}$ & $\begin{array}{c}3.963 \\
(0.191)\end{array}$ & $\begin{array}{c}2.761 \\
(0.222)\end{array}$ & $\begin{array}{c}2.869 \\
(0.172)\end{array}$ \\
\hline Inflation & $\begin{array}{l}0.051^{*} \\
(0.084) \\
\end{array}$ & $\begin{array}{l}0.064^{* *} \\
(0.009) \\
\end{array}$ & $\begin{array}{c}0.031 \\
(0.168)\end{array}$ & $\begin{array}{l}0.051^{*} \\
(0.051)\end{array}$ & $\begin{array}{c}0.138 * * \\
(0.010)\end{array}$ & $\begin{array}{c}0.025 \\
(0.307)\end{array}$ & $\begin{array}{c}0.023 \\
(0.232)\end{array}$ & $\begin{array}{c}0.031 \\
(0.176)\end{array}$ & $\begin{array}{c}0.030 \\
(0.179)\end{array}$ \\
\hline Moral Hazard Index & & & $\begin{array}{l}0.719 * * \\
(0.000) \\
\end{array}$ & & & $\begin{array}{l}1.442 * * \\
(0.009)\end{array}$ & $\begin{array}{c}2.132 * * \\
(0.002)\end{array}$ & $\begin{array}{l}0.716^{* *} \\
(0.000)\end{array}$ & $\begin{array}{c}0.769 * * \\
(0.001)\end{array}$ \\
\hline Diversification Index & & & & $\begin{array}{c}-13.443 * * \\
(0.012)\end{array}$ & & & & & \\
\hline Diversification Index*Ln (GDP) & & & & $\begin{array}{c}0.497^{* *} \\
(0.014) \\
\end{array}$ & & & & & \\
\hline Limitations on Foreign Bank Entry/Ownership & & & & & $\begin{array}{l}1.911^{*} \\
(0.052) \\
\end{array}$ & & & & \\
\hline Moral Hazard Index*Political Openness & & & & & & $\begin{array}{c}-0.513 * * \\
(0.013)\end{array}$ & & & \\
\hline Political Openness & & & & & & $\begin{array}{c}0.762 \\
(0.141) \\
\end{array}$ & & & \\
\hline Moral Hazard Index*Rule of Law & & & & & & & $\begin{array}{c}-0.288 * * \\
(0.035)\end{array}$ & & \\
\hline Rule of Law & & & & & & & $\begin{array}{c}-0.295 \\
(0.535) \\
\end{array}$ & & \\
\hline Moral Hazard Index*Official Supervisory Power & & & & & & & & $\begin{array}{l}-0.031 \\
(0.842) \\
\end{array}$ & \\
\hline Moral Hazard Index*Capital Regulatory Index & & & & & & & & & $\begin{array}{c}-0.131 \\
(0.600)\end{array}$ \\
\hline
\end{tabular}

Note: Each column gives complete logit results and the P-values in parentheses under the estimated coefficients are based on Huber/White robust standard errors. ** indicates significant at the 0.05 level, while * indicates significant at the 0.10 level.

The sample for regression 2 is restricted to countries with some equity market activity (i.e., to countries where the IFC obtains trading data) and the following indices are principal component versions: Entry into Banking Requirements, Capital Regulatory Index, Restrictions on Bank Activities, Private Monitoring Index, and Official Supervisory Power. 
Table 5

Bank Development, Regulation and Supervision: Instrumental Variables

Dependent Variable: Bank Development (Bank Credit to the Private Sector as Share of GDP)

\begin{tabular}{|c|c|c|c|c|c|c|c|c|c|c|c|c|c|}
\hline & 1 & 2 & 3 & 4 & 5 & 6 & 7 & 8 & 9 & 10 & 11 & 12 & 13 \\
\hline Entry into Banking Requirements Index & $\begin{array}{l}-0.536 \\
(0.390)\end{array}$ & & & & & & & & & & & & \\
\hline Limitations on Foreign Bank Entry/Ownership & & $\begin{array}{l}-0.388^{*} \\
(0.092)\end{array}$ & & & & & & & & & & & \\
\hline Entry Applications Denied & & & $\begin{array}{c}-0.785 * * \\
(0.004)\end{array}$ & & & & & & & & & & \\
\hline Capital Regulatory Index & & & & $\begin{array}{c}0.340^{* *} \\
(0.024)\end{array}$ & & & & & & & & & \\
\hline Restrictions on Bank Activities Index & & & & & $\begin{array}{c}-0.145^{* *} \\
(0.010)\end{array}$ & & & & & & & & \\
\hline Private Monitoring Index & & & & & & $\begin{array}{r}0.252^{* *} \\
(0.001)\end{array}$ & & & & & & & \\
\hline Moral Hazard Index & & & & & & & $\begin{array}{c}0.109 \\
(0.387)\end{array}$ & & & & & & \\
\hline Official Supervisory Power Index & & & & & & & & $\begin{array}{l}-0.167 \\
(0.148)\end{array}$ & & & & & \\
\hline Prompt Corrective Power Index & & & & & & & & & $\begin{array}{l}-2.419 \\
(0.518)\end{array}$ & & & & \\
\hline No Foreign Loans & & & & & & & & & & $\begin{array}{l}-0.624 * \\
(0.080)\end{array}$ & & & \\
\hline Government-Owned Banks & & & & & & & & & & & $\begin{array}{c}-2.075 * * \\
(0.044)\end{array}$ & & \\
\hline Supervisory Independence & & & & & & & & & & & & $\begin{array}{l}0.162^{*} \\
(0.080)\end{array}$ & \\
\hline Multiple Supervisory Agencies & & & & & & & & & & & & & $\begin{array}{c}2.498 \\
(0.295)\end{array}$ \\
\hline Constant & $\begin{array}{l}-0.210 \\
(0.835)\end{array}$ & $\begin{array}{c}0.290 * * \\
(0.000)\end{array}$ & $\begin{array}{c}0.460^{* *} \\
(0.000)\end{array}$ & $\begin{array}{l}0.394 * \\
(0.077)\end{array}$ & $\begin{array}{l}0.308^{* *} \\
(0.000)\end{array}$ & $\begin{array}{l}0.216^{* *} \\
(0.002)\end{array}$ & $\begin{array}{c}0.296 \\
(0.139)\end{array}$ & $\begin{array}{c}0.137 \\
(0.494)\end{array}$ & $\begin{array}{l}-0.598 \\
(0.742)\end{array}$ & $\begin{array}{l}0.421^{* *} \\
(0.000)\end{array}$ & $\begin{array}{l}0.575^{* *} \\
(0.002)\end{array}$ & $\begin{array}{c}0.146 \\
(0.421)\end{array}$ & $\begin{array}{c}0.420^{* *} \\
(0.000)\end{array}$ \\
\hline OIR-Test $^{1}$ & 2.30 & 2.07 & 1.89 & 1.14 & 4.76 & 1.69 & 4.41 & 5.15 & 0.34 & 4.85 & 2.82 & 6.76 & 0.30 \\
\hline $\mathrm{N}$ & 77 & 59 & 61 & 76 & 76 & 77 & 49 & 77 & 75 & 77 & 69 & 76 & 76 \\
\hline
\end{tabular}

Notes: P-values are in parentheses under the estimated coefficients, using a GMM instrumental variables regression. ** indicates significant at the 0.05 level, while * indicates significant at the 0.10 level.

Each column represents a separate regression of Bank Development on Common Law, French Civil Law, German Civil Law, Socialist Law, and the variable listed in the first column.

Instruments: Regious composition variables (Catholic, Muslim, and Other Denomination variables), Legal origin dummy variables (Common Law, French Civil Law,

German Civil Law, and Socialist Law), and latitudinal distance from the equator.

5\% Critical Valos foridual.

$5 \%$ Critical Values for OIR Test ( 3 df) $) 7.82$.

For regressions 2 and 7, there are no socialist legal origin countries with data so the Socialist Law dummy variable is excluded.

The following indices are principal component versions: Entry into Banking Requirements, Capital Regulatory Index, Restrictions on Bank Activities, Private Monitoring Index,

Official Supervisory Power, and Prompt Corrective Power. 